\title{
Özengen Müzik Eğitimi Kurumlarında Keman Derslerini Yürüten Öğretmenlerin Karşılaştığ1 Problemler ${ }^{1}$
}

\author{
DOI: 10.26466/opus.910883
}

\author{
$*$ \\ $\underline{B e y z a ~ T o k a t l}^{*}$ - Önder Mustul ${ }^{* *}$ \\ * Dr. Öğr., Necmettin Erbakan Üniversitesi Eğitim Bilimleri Enstitüsü, Konya/Türkiye \\ E-Posta: beyzattokatli@gmail.com \\ ORCID: $\underline{0000-0002-9388-6714}$ \\ ** Dr. Öğr. Üyesi, Necmettin Erbakan Üniversitesi, AKEF, Konya/Türkiye \\ E- Posta: ondermustul@hotmail.com \\ ORCID: 0000-0002-7045-5145
}

Öz

Özengen müzik eğitimi, genel müzik eğitimini destekleyici ve mesleki müzik eğitimine hazırlayııı rolü ile müzik eğitiminin önemli bir alt boyutudur. Son yillarda özengen müzik eğitimi alannda yapllan çalışmalarm, bu hedefe yönelik müzik eğitimi veren kurumlarda yoğunlaştı̆̆ı dikkat çekmektedir. Özengen müzik eğitimi kurumlarnnda müzik eğitiminin diğger alanlarnna knyasla çalgı eğitimi alanının ön plana çıktı̆̆ görülmektedir. Bu araştırmada da Millî Eğitim Bakanlı̆̆ı'na bağh özengen müzik eğitimi kurumlarnnda keman derslerini yürüten öğretmenlerin ö̆grenci, öğrenci velisi ve kurum kaynakl karşılaşttğı problemleri tespit etmek ve elde edilen bulgulara göre çözüm önerileri sunmak amaçlanmıştr. Nitel veri toplama yöntemi işe koşulan bu araştırmada verilerin toplanabilmesi için, nitel araştırmalarda sıklkla kullanlan "gözlem", "görü̧̧me" ve "doküman incelemesi" tekniklerinden görü̧sme tekniği kullamlmış, görüşme formu yoluyla Millî Ĕ̈itim Bakanlı̆̆ı'na bağh özengen müzik eğitimi kurumlarnnda keman derslerini yürüten 25 öğretmenden görüş alma yoluna gidilmiş ve alman cevaplara betimsel analiz uygulanmıştır. Elde edilen bulgulara göre; özengen müzik eğitimi kurumlarnnda keman derslerini yürüten öğretmenlerin büyük bir kısmınin çalışma koşullarndan memnun olmadığı ve öğrencilerin bireysel çalgı çalş̧malarmı yetersiz bulduğu, özengen müzik eğitimi kurumlarnnn büyük bir kısminda keman eğitimini destekleyici derslerin verilmediğĭ, öğrencilerin birlikte düzenli olarak çalgı çalabileceği bir toplu ders olmadı̆̆ ve kurumun öğrencileri kent içerisindeki sanatsal faaliyetlere yönlendirmediği sonuçlarna ulaşılmıştır. Bu sonuçlara göre; özengen müzik eğitimi kurumlarnnda bireysel yapılan keman dersine ek olarak işitme, solfej ve orkestra derslerinin verilmesi ve bu kurumlarm kent içerisindeki sanatsal faaliyetleri takip ederek öğrencilerini yönlendirmesi, ögrretmenlerin dinlenme, beslenme gibi temel ihtiyaçlarnnn göz önünde bulundurulması, bu kurumlardaki ders programlarmin yoğunluğunun azaltılması, bir gün içerisinde art arda 8 saatten fazla ders yapılmaması, ders sürelerinin maksimum 40 veya $45 \mathrm{dk}$. olması ve öğretmenlerin verimlilĭginin düşmemesi adına dersler arasında mutlaka boşlukların olması önerilmektedir.

Anahtar Kelimeler: Müzik Eğitimi, Özengen Müzik Eğitimi, Keman Eğitimi.

${ }^{1}$ Bu makale Dr. Öğr. Üyesi Önder Mustul danışmanlığında yürütülen, Temmuz 2020'de savunulan ve başarılı bulunan aynı isimli yüksek lisans tezinden türetilmiştir. Çalışmanın görüşmeye ilişkin verileri 2019 yılııın eylül, ekim ve kasım aylarında toplandığından etik kurul izni alınmamıştır. 


\title{
The Problems Faced by the Teachers Who Conduct Violin Lessons in the Institutions Teaching Amateur Music
}

\begin{abstract}
Amateur music education is an important sub-dimension of music education with its supporting and preparing role for general music education. It is noteworthy that, in recent years, the research conducted in the field of amateur music education has concentrated on the institutions that offer education towards this goal. It is also seen that, compared with other fields of education, instrument education comes to prominence in the institutions of amateur music education. In this research, the aim is to identify the problems faced by teachers conducting violin lessons in the institutions of amateur music education under the Ministry of National Education and to offer solutions based on the findings. The qualitative data collection method was employed in collecting data in this research; the interview technique was used out of the techniques often used in qualitative research, which are "observation", "interview" and "document review". An interview form was used and descriptive analysis was applied to the answers received from 25 teachers who conducted violin lessons in amateur music education institutions under the Ministry of National Education. From the findings, a greater proportion of teachers in violin lessons music education institutions amateur in carrying out their working conditions and the work of individual students unsatisfactory you are not satisfied with the instrument found in most of the institutions supporting education courses for his violin, amateur music education is not given, the students and the institution is not cumulative instrument that can play together regularly a course in artistic activities within the city, the orientation of the students of the conclusions were reached. According to these results; in addition to individual violin lessons music education institutions made, amateur hearing, sight reading and ensemble and artistic activities, the provision of students with orientation courses follow the teachers of these institutions within the city, the remainder of the consideration of basic needs such as nutrition, the reduction of the intensity of the curriculum at these institutions, one day is not more than 8 hours in a row made in the course of the course of the time up to 40 or $45 \mathrm{~min}$. It is decidedly suggested that there should be gaps between the lessons in order to ensure that the productivity of teachers does not decrease.
\end{abstract}

Key Words: Music Education, Amateur Music Education, Violin Education. 


\section{Giriş}

İnsan, doğumundan itibaren bir gelişim sürecine girer. Eğitim ise, yaşam boyu süregelen, hayatımızın hemen her alanında yer alan bir kavramdır. Eğitim yoluyla insanoğlu farklı birçok alanda yeni bilgiler, beceriler, deneyimler kazanarak kendini geliştirmeye devam etmektedir.

Sanat eğitimi eğitimin, müzik eğitimi ise sanat eğitiminin çok önemli bir alt boyutudur. "Müzik eğitimi, genel müzik eğitimi, mesleki müzik eğitimi ve özengen müzik eğitimi olarak üç ana türe ayrılır. Genel müzik eğitimi, müzikle ilişkisi ne olursa olsun herkes için gereklidir ve herkese yöneliktir. Mesleki müzik eğitimi, müziğe üst düzeyde yetenekli olup müziği kendisine bir iş, meslek, ciddi-sürekli uğraş, görev alanı veya çalışma alanı olarak seçenlere yöneliktir. Özengen müzik eğitimi ise, müziğe özel ilgisi, isteği ve yatkınlığı olup müziği kendisi için bir düşkü (hobi) alanı olarak seçenlere dönüktür"' (Uçan, 1997, s.7-8).

Uçan'a göre (1997, s.32) özengen müzik eğitimi müziği maddi bir karş1lık beklemeden, sadece zevk ve doyum sağlamak için müzik yapan amatör müzikçiler yetiştirmeyi amaçlar. Müziksel öğrenmenin son derece kalıcı olduğu özengen müzik eğitiminde bireyin yatkınlığı, yeteneği, ilgisi ve isteği doğrultusunda gelişim kaydetmesi önem arz etmektedir.

“Özengen müzik eğitimi ülkemizde özel-kurumsal müzik dershaneleri, dernekler, vb. kurum ve kuruluşlar eliyle yürütülmektedir" (Aksoy, 2015, s.1). "Müzik dershaneleri, mesleki ve meslek dışı müzik eğitimini destekleyici bir konumdadır. Bu dershaneler müzik eğitimini hem amatör olarak sürdürmeyi düşünenlere hem de mesleki olarak sürdürmeyi düşünenlere eğitim hizmeti sağlamaktadır" (Karan, 2011, s.9).

Müzik eğitimi içerik açısından ele alındığında; işitme (kulak eğitimi), ses eğitimi, çalgı eğitimi gibi alanları içerir. Müzik eğitiminin en önemli boyutlarından biri de çalgı eğitimidir. Hancıoğlu (2010)'na göre; Türkiye'de MEB'in sağlamış olduğu müzik eğitimi çalgı eğitimi bakımından yetersizdir. Sınıflardaki öğrenci sayısının fazla olması, sosyoekonomik koşullar ve benzeri sebeplerden dolayı okullarda genel olarak çalgı eğitimi sağlıklı yapılamamaktadır. Bireylerin çalgı eğitimi isteği varsa, okul d1şında temin etmeleri gerekmektedir. Bu eğitim de özel dersler ile ya da müzik kursları (dershaneleri) aracılığı ile yapılmaktadır. Son yıllarda sayıları artan özengen müzik eğitimi veren kurumların, bireylerin müziksel 
anlamda gelişmelerinde büyük önem taşıdığı düşünülmektedir. Bu kurumlarda yaylı çalgılardan nefesli çalgılara, vurmalı çalgılardan geleneksel çalgılara kadar oldukça geniş bir yelpazede, farklı zevk ve beğenilere sahip insanlara hitap edebilmek üzere çeşitli çalgıların eğitimi sürdürülmektedir.

Yaylı çalgılar ailesinin en küçük üyesi olan keman, örgün ve yaygın eğitim kapsamında, çalg1 eğitiminin yapıldığı çoğu ortamda yaygın olarak öğretilen bir çalgıdır (Uslu, 2012, s.2). Son yıllarda keman, taşıma kolaylığı, başlangıç aşamasında çok maliyetli olmaması ve kendine farklı kültür ve coğrafyalarda yer bulmuş her tür müziğe elverişli evrensel bir çalgı olması sebebiyle sıkça tercih edilen bir çalgıdır. Bu yoğun talep sebebiyle bugün özengen müzik eğitimi veren kurumların neredeyse tamamında keman eğitimi de verildiğini söylemek mümkündür. Özdemir (2015)'de günümüzde keman çalmayı öğrenme isteğinin oldukça yaygınlaştığını ve özellikle son yıllarda Uzak Doğu kökenli (Çin) fabrikasyon keman üretiminin artmasının, maddi olanaklar açısından çalgıya daha kolay ulaşabiliyor olmayı sağladığını ve bu durumunda birçok sosyokültürel katmandan insanın keman eğitimi alma şansına sahip olmasını kolaylaştırdığını, dolayısıyla özengen keman eğitiminin yaygınlaştığını belirtmiştir.

Günümüzde ülkemizin hemen her ilinde çalgı eğitimi veren özengen müzik eğitimi kurumlarının sayısı git gide artmaktadır ve dolayısıyla müzik eğitiminin her boyutunda olduğu gibi özengen müzik eğitimi boyutunda da verilen eğitimin niteliğinin artırılması önemlidir. Uslu'nun (2012, s.3) da belirttiği üzere ülkemizde yaygın olarak sürdürülen keman eğitiminde, birbirine benzer kurumlarda ya da ortamlarda, nitelik açısından ciddi farklılıklar olduğu gözlemlenmektedir.

Müzik eğitiminin hem mesleki hem de özengen boyutunda keman eğitiminin oldukça önemli bir yeri vardır. Fakat ilgili literatür tarandığında, özellikle özengen müzik eğitiminde keman eğitim-öğretimine ilişkin az sayıda araştırma olması dikkat çekmiştir. Özengen müzik eğitiminin genel müzik eğitimini destekleyici ve mesleki müzik eğitimine hazırlayıcı bir köprü olması ve özengen müzik eğitimi alanında keman derslerini yürüten öğretmenlerin ne tür problemler ile karşılaştığına ilişkin sonuçlara yeterli düzeyde ulaşılamaması, bu araştırma için önemli bir çıkış noktası 
olmuştur. Bu genel düşünce ışığında araştırmanın problem cümlesi şu şekilde oluşturulmuştur;

“Özengen müzik eğitimi kurumlarında keman derslerini yürüten öğretmenlerin karşılaştı̆̆ 1 problemler nelerdir?"

Bu problem ışığında araştırmanın alt problemleri şu şekilde oluşturulmuştur;

1- Özengen müzik eğitimi kurumlarında keman derslerini yürüten öğretmenlerin öğrencinin performansı ile ilgili karşılaştı̆̆ı problemler nelerdir?

2- Özengen müzik eğitimi kurumlarında keman derslerini yürüten öğretmenlerin çalıştıkları kurumun işleyişi ile ilgili problemleri nelerdir?

3- Özengen müzik eğitimi kurumlarında keman derslerini yürüten öğretmenlerin ders yürüttüğü öğrencilerin aileleri ile ilgili problemler nelerdir?

\section{Araştırmanın Amacı}

Özengen müzik eğitimi, genel müzik eğitimini destekleyici ve mesleki müzik eğitimine hazırlayıcı özellikleri ile müzik eğitiminin oldukça önemli bir alt boyutudur. Özengen müzik eğitimi kurumlarındaki problemlerin belirlenmesi ve çözüm önerilerinin sunulması amacıyla yapılan araştırmaların bu kurumlarda yürütülen eğitimin niteliğinin artmasına yardımcı olacağı düşünülmektedir. Bu düşünceden yola çıkarak araştırmanın genel amacı; özengen müzik eğitimi kurumlarında keman derslerini yürüten öğretmenlerin karşılaştığı sorunları tespit etmek ve konuya ilişkin çözüm önerileri sunmaktır.

\section{Araştırmanın Önemi}

Bu araştırma; özengen müzik eğitimi kurumlarında keman derslerini yürüten öğretmenlerin karşılaştığ1 problemlerin tespit edilebilmesi ve konuya ilişkin çözüm önerilerinin sunulması açısından, özengen müzik eğitimi konusunda sayısı oldukça sınırlı olan araştırmalar içerisinde, özengen müzik eğitimi kurumlarında keman derslerini yürüten öğretmenlerle 
ilgili yapılan ilk araştırma olması açısından, özengen müzik eğitimi kurumlarında keman derslerinin daha nitelikli şekilde yürütülebilmesine katkı sağlayacağının düşünülmesi açısından, özengen müzik eğitimi ile ilgilenen öğretmen, veli ve öğrencilere bir kaynak niteliği taşıması açısından, ilgili konularda daha sonra yapılacak araştırmalar için bir kaynak niteliği taşıması açısından önemlidir.

\section{Sayıltı}

Bu araştırmada MEB'e bağlı olarak eğitim-öğretim faaliyetlerini sürdüren özengen müzik eğitimi kurumlarının daha kapsamlı bir programa ve sistemli bir işleyişe sahip olduğu varsayılmıştır.

\section{Sinırlılıklar}

Bu araştırma; müzik eğitiminin bir alt boyutu olan özengen müzik eğitimi ile, farklı illerde ve farklı özengen müzik eğitimi kurumlarında keman dersini yürüten, ulaşılabilen ve araştırmaya gönüllü olarak katılan öğretmenlerin görüşleri ile, Milli Eğitim Bakanlığı'na bağlı olan özengen müzik eğitimi kurumları ile, araştırma sürecinde ulaşılabilen kaynaklar ile sınırlidır.

\section{Yöntem}

\section{Çalışma Grubu}

$\mathrm{Bu}$ araştırmanın katılımcıları; İstanbul, Konya, İzmir, Ankara, Amasya, Antalya, Balıkesir, Batman, Çanakkale, Denizli ve Kocaeli illerinde Millî Eğitim Bakanlığı' na bağlı özengen müzik eğitimi kurumlarında fiilen keman derslerini yürüten ve ulaşılabilen, araştırmaya gönüllü olarak katkıda bulunmak isteyen 25 keman öğretmeninden oluşmuştur. 
Tablo 1. Araştırmaya katılan öğretmenlerin görev yaptı̆̆ı il ve kurum adı

\begin{tabular}{|c|c|c|c|}
\hline$\overline{\mathrm{Il}}$ & Kurum Ad1 & $\mathrm{f}$ & $\%$ \\
\hline \multirow{5}{*}{ İstanbul } & Kartal Sanat Tiyatrosu & 1 & 4 \\
\hline & OD Müzik & 1 & 4 \\
\hline & BT Müzik ve Sahne Sanatları & 1 & 4 \\
\hline & Koza Bale ve Güzel Sanatlar Kursu & 1 & 4 \\
\hline & Başakşehir Bilgievleri & 1 & 4 \\
\hline \multirow{5}{*}{ Konya } & Öner Mustul Sanat Merkezi & 1 & 4 \\
\hline & Duru Sanat Merkezi & 1 & 4 \\
\hline & Yakamoz Sanat Merkezi & 1 & 4 \\
\hline & Özel Mart Akademi Sanat Kursu & 2 & 8 \\
\hline & Cihan Orhan Müzik Merkezi & 1 & 4 \\
\hline \multirow{2}{*}{ Ankara } & Vivo Sanat & 1 & 4 \\
\hline & Arya Sanat Ses Müzik Merkezi & 1 & 4 \\
\hline Balıkesir & Burhaniye Sosyal Etkinlik Merkezi & 1 & 4 \\
\hline Batman & Arya Müzik & 1 & 4 \\
\hline İzmir & Özel Laterna Müzik Kursu & 1 & 4 \\
\hline Çanakkale & E-Stüdyo Sanat Merkezi & 1 & 4 \\
\hline Antalya & Trio Sanat Merkezi & 1 & 4 \\
\hline Kocaeli & Filiz Özer Müzik ve Bale Kursu & 1 & 4 \\
\hline \multicolumn{4}{|l|}{$\overline{\text { Amasya }}$} \\
\hline Kocaeli & Kurum adını paylaşmak istemeyen & 6 & 24 \\
\hline İstanbul & & & \\
\hline \multicolumn{4}{|l|}{ İzmir } \\
\hline Toplam & & 25 & 100 \\
\hline
\end{tabular}

\section{Verilerin Toplanması ve Analizi}

Araştırma, bilimsel araştırma modellerinden biri olan genel tarama modelinde betimsel bir çalışmadır. Araştırma verilerine ulaşabilmek için nitel araştırmalarda sıkça kullanılan görüşme tekniğine başvurulmuştur.

“Nitel araştırmalar; gözlem, görüşme ve doküman analizi gibi nitel veri toplama yöntemlerinin kullanıldığı, algıların ve olayların doğal ortamda gerçekçi ve bütüncül biçimde ortaya konulmasına yönelik nitel bir sürecin izlendiği araştırmalardır" (Yıldırım ve Şimşek, 2018: 41). Araştırmaya kuramsal bir temel sağlamak için müzik eğitimi, özengen müzik eğitimi, çalg1 eğitimi ve keman eğitimine ilişkin kaynaklar taranarak incelenmiştir. Tarama sonucu ulaşılan veriler ve araştırmanın genel amacı doğrultusunda özengen müzik eğitimi kurumlarında keman derslerini yürüten öğretmenlerin karşılaştığı sorunları tespit etmek üzere hazırlanan görüşme soruları, uzman görüşleri ve pilot uygulama ile geliştirilip belirlenen çalışma grubu üzerinde uygulanarak bulgulara ulaşılmıştır. Araştırmada, araştırmacı tarafından uzman görüşü alınarak hazırlanan tamamı 
açık uçlu toplam 30 sorudan oluşan yapılandırılmış görüşme formu kullanılmıştır. Görüşme formu hazırlanırken soru havuzunda 39 soru hazırlanmış, daha sonra soru sayısı 30'a indirgenmiştir. Görüşme formundaki sorular öğrenci performansları ile ilgili problemler, çalışılan kurumun işleyişi ile ilgili problemler ve öğrenci ailelerine ilişkin problemler olmak üzere üç tema altında toplanmıştır. Görüşmeler 2019 yılının güz yarıyılında, ses kayıt cihazı yoluyla kayıt altına alınarak gerçekleştirilmiştir. Görüşmeler kayıt altına alınmadan önce katılımcılara gerekli açıklamalar yapılmış, ses kaydı için izinleri alınmıştır. Katılımcıların verecekleri cevapların gizli tutulacağı belirtilerek içten ve dürüst cevap vermelerinin önemi vurgulanmıştır. Ses kayıtları, verilerin daha kolay analiz edilebilmesi amacıyla araştırmacı tarafından yazıya çevrilmiştir. Bulgular bölümünde çalışma grubunda yer alan katılımcı görüşlerine doğrudan alıntılar ile yer verilmiştir. Verilerin analizi sürecinde görüşme yapılmış her bir katılımcı için Ö1, Ö2, Ö8 vb. şeklinde kodlama yapılmıştır. Görüşmeler sonucunda elde edilen verilere, veri toplama tekniğine uygun olarak betimsel analiz yapılmıştır. Veriler, tanımlayıcı istatiksel metotlardan frekans ve yüzde hesaplamaları kullanılarak tablolaştırılmıştır.

\section{Bulgular}

Bu bölümde, araştırma soruları yoluyla toplanan verilerin analizi sonucunda elde edilen bulgulara ve bulgulara ilişkin yorumlara yer verilmiştir.

\section{Birinci Alt Probleme İlişkin Bulgular ve Yorumlar}

Tablo 2. Öğretmenlerin çalgıya başlangıçöncesinde dikkat ettiği ölçütler

\begin{tabular}{lll}
\hline Ölçütler & $\mathbf{f}$ & $\%$ \\
\hline Öğrencinin işitme yeteneğinin iyi olması & 12 & 31,6 \\
Öğrencinin parmak boyu, esnekliği ve tırnak yapısı & 9 & 23,7 \\
Öğrencinin çalgıya ilgi duyması & 7 & 18,5 \\
Öğrencinin vücut yapısı & 5 & 13,2 \\
Öğrencinin kendi isteği ile başlaması & 2 & 5,2 \\
Öğrencinin yaşı & 2 & 5,2 \\
Dikkat ettiğim bir ölçüt yok & 1 & 2,6 \\
\hline
\end{tabular}


Tablo 2'ye baktığımızda öğretmenlerin büyük bir kısmının çalgıya başlangıç öncesinde öğrencinin işitme yeteneğinin iyi olmasına ya da öğrencinin parmak boyu, esnekliği ve tırnak yapısına dikkat ettiği görülmektedir. Diğer ölçütler azalan değerler içerisinde "öğrencinin çalgiya ilgi duyması, öğrencinin vücut yapısı, öğrencinin kendi isteği ile başlaması ve öğrencinin yaşı" olarak ifade edilmiştir. Bir öğretmen ise dikkat ettiği bir ölçüt olmadığını dile getirmiştir.

Tablodan elde edilen verilere göre öğretmenlerin dörtte üçü çalgıya başlangıç öncesinde öğrencilerin fiziksel ya da işitsel özelliklerine dikkat ettiğini belirtmiştir. Verimli ve uzun soluklu bir keman eğitimi için, mesleki herhangi bir amaç güdülmese dahi, başlangıç öncesinde fiziksel ve işitsel özelliklere dikkat edilmesinin önemli olduğu düşünülmektedir. Ö8: "Hobi olarak bu eğitimi aldıkları için sadece istekli olması benim için yeterlidir."

Ö-16: “Öğrenciye öncelikle bir işitme testi yapryoruz, bu test sonucunda işitme becerisi yeterli ise fiziksel özelliklerine bakıyoruz. Fiziksel özellikleri de yeterli ise eğitime başlıyoruz."

Ö-25: "Parmaklarının ince ve uzun olması benim için önemli bir ölçüt."

Tablo 3. Öğretmenlere göre keman çalmak için gerekli fiziksel ve işitsel özelliklere sahip olma durumunun önemi ve öğretmenlerin fiziksel ve işitsel özellikleri keman çalmak için yeterli olmayan öğrenciler ile çalışma durumu

\begin{tabular}{|c|c|c|c|c|c|}
\hline Görüşler & $f$ & $\%$ & Çalışma Durumu & $f$ & $\%$ \\
\hline $\begin{array}{l}\text { Gerekli fiziksel ve işitsel özel- } \\
\text { liklere sahip olmak çok önemli- } \\
\text { dir }\end{array}$ & 16 & 64 & $\begin{array}{l}\text { Fiziksel ve işitsel özellikleri yeterli } \\
\text { olmayan öğrenciler ile çalışıyo- } \\
\text { rum }\end{array}$ & 14 & 56 \\
\hline $\begin{array}{l}\text { Gerekli fiziksel ve işitsel özel- } \\
\text { liklere sahip olmak önemli de- } \\
\text { ğildir }\end{array}$ & 9 & 36 & $\begin{array}{l}\text { Fiziksel ve işitsel özellikleri yeterli } \\
\text { olmayan öğrenciler ile çalışmıyo- } \\
\text { rum }\end{array}$ & 11 & 44 \\
\hline Toplam & 25 & 100 & & 25 & 100 \\
\hline
\end{tabular}

Tabloda görüldügü üzere öğretmenlerin büyük bir kısmı keman çalmak için gerekli fiziksel ve işitsel özelliklere sahip olma durumunun önemli olduğunu düşünmektedir. Buna ek olarak öğretmenlerin çoğunluğu fiziksel ve işitsel özellikleri keman çalmak için yeterli olmayan öğrenciler ile çalıştı̆̆ını dile getirmiştir. Verilere göre, 9 öğretmen keman çalmak için gerekli fiziksel ve işitsel özelliklere sahip olmanın önemli olmadığını düşünmesine rağmen; 14 öğretmen fiziksel ve işitsel özellikleri keman çalmak için yeterli olmayan öğrenciler ile çalıştığını dile getirmiştir. 
Bu durumda keman çalmak için gerekli fiziksel ve işitsel özelliklere sahip olmanın önemli olduğunu düşünmesine rağmen, fiziksel ve işitsel özellikleri keman çalmak için yeterli olmayan öğrenciler ile çalışmak zorunda kalan 5 öğretmen bulunmaktadır.

Tablo 4. Öğretmenlerin fiziksel ve işitsel özellikleri keman çalmak için yeterli olmayan öğrenciler ile çalışma ve çalışmama nedenleri

\begin{tabular}{|c|c|c|c|c|c|}
\hline Çalışıyorum & $\mathbf{f}$ & $\%$ & Çalışmıyorum & $\mathrm{f}$ & $\%$ \\
\hline $\begin{array}{l}\text { Öğrencinin ilgili ve istekli ol- } \\
\text { ması daha önemlidir. }\end{array}$ & 4 & 28,7 & $\begin{array}{l}\text { Fiziksel ve işitsel gelişimi için öğ- } \\
\text { renciyi başka çalgıya (özellikle pi- } \\
\text { yanoya) yönlendiririm. }\end{array}$ & 11 & 100 \\
\hline $\begin{array}{l}\text { Kurum patronunun ticari istek- } \\
\text { leri nedeniyle çalışıyorum. }\end{array}$ & 2 & 14,3 & & & \\
\hline $\begin{array}{l}\text { Müzik yapmak herkesin hakkı- } \\
\text { dır. }\end{array}$ & 2 & 14,3 & & & \\
\hline $\begin{array}{l}\text { Öğrencinin fiziksel ve işitsel } \\
\text { özelliklerini geliştirmek ama- } \\
\text { cıyla çalışıyorum. }\end{array}$ & 2 & 14,3 & & & \\
\hline $\begin{array}{l}\text { Ebeveyn isteği nedeniyle çalış1- } \\
\text { yorum. }\end{array}$ & 1 & 7,1 & & & \\
\hline $\begin{array}{l}\text { Öğrencinin diğer alanlardaki } \\
\text { gelişimini desteklemesi ama- } \\
\text { clyla çalışıyorum. }\end{array}$ & 1 & 7,1 & & & \\
\hline $\begin{array}{l}\text { Tedavi-terapi amaçlı çalışıyo- } \\
\text { rum. }\end{array}$ & 1 & 7,1 & & & \\
\hline $\begin{array}{l}\text { Öğrenciler çok ısrarcı olduğu } \\
\text { için çalışıyorum. }\end{array}$ & 1 & 7,1 & & & \\
\hline
\end{tabular}

Tablo 4'te görüldüğü üzere fiziksel ve işitsel özellikleri keman çalmak için yeterli olmayan öğrenciler ile çalışan öğretmenlerin çoğunluğu öğrencinin ilgili ve istekli olmasının daha önemli olduğu görüşünü dile getirmiştir. Öğretmenlerin üçte birinin kendi isteği dışında (kurum patronu isteği, ebeveyn isteği, öğrenci isteği) fiziksel ve işitsel özellikleri keman çalmak için yeterli olmayan öğrencilerle çalışması oldukça dikkat çekicidir.

Tabloda görüldüğü üzere fiziksel ve işitsel özellikleri keman çalmak için yeterli olmayan öğrenciler ile çalışmayan öğretmenlerin tamamı, böyle bir durumda öğrenciyi fiziksel ve işitsel gelişimi açısından başka bir çalgıya, özellikle piyanoya yönlendirdiğini ifade etmiştir. Piyanonun keman aksine vücut tarafından taşınmayı gerektirmemesi ve tuşlu bir çalgı olması, fiziksel özellikleri yetersiz olan öğrencilerde kolaylık sağlayabilirken, yine doğru akortlanmış bir piyanoda öğrencinin sürekli olarak temiz 
sesleri çoksesli duymasının da işitsel gelişimine oldukça katkı sağlayacağ1 düşünülmektedir.

Ö-1: "Tüm olumsuz özelliklerine rağmen ilgili ve emek vermeye hazırsa bu tarz öğrenciler ile çalışıyorum."

Ö-2: "Fiziksel ve işitsel özellikleri yetersiz olan öğrencilerle çalışıyorum çünkü her bireyin çalgı eğitimi alması gerektiğini düşünüyorum. Akademik başarılarına, analitik düşünmelerine büyük oranda katkı sağlıyor."

Ö-15: "Kurum patronunun ticari istekleri doğrultusunda fiziksel ve işitsel özellikleri keman çalmak için yeterli olmayan öğrenciler ile çalışmak zorunda kaliyorum."

Ö-22: “Özellikle işitsel olarak yetersiz gördü̈̆̈̈m öğrencileri öncelikle piyano dersine yönlendiriyorum."

Tablo 5. Öğretmenlere göre keman çalmak için gerekli fiziksel ve işitsel özelliklere sahip olma durumunun önemli veya önemsiz olmasının nedenleri

\begin{tabular}{|c|c|c|c|c|c|c|}
\hline Çok önemlidir & f & $\%$ & Önemli değildir & f & $\%$ & \\
\hline $\begin{array}{l}\text { Kemanın perdesiz bir çalgı olması } \\
\text { nedeniyle işitsel yetenekleri yeterli } \\
\text { olmayan öğrenciler ilerleme kayde- } \\
\text { demez. }\end{array}$ & 9 & 56,3 & $\begin{array}{l}\text { Öğrencinin istekli olması daha } \\
\text { önemlidir. }\end{array}$ & 4 & & 4,5 \\
\hline $\begin{array}{l}\text { Fiziksel özellikleri keman çalmak } \\
\text { için yetersiz olan öğrencilerin çalg1- } \\
\text { daki gelişimi ve başarısı olumsuz } \\
\text { anlamda etkilenir. }\end{array}$ & 4 & 25 & $\begin{array}{l}\text { Hobi olarak devam ettirilen ke- } \\
\text { man eğitiminde işitsel ve fiziksel } \\
\text { özellikler önemli değildir. }\end{array}$ & 2 & & 2,2 \\
\hline $\begin{array}{l}\text { Öğrencinin ilerde mesleki bir dü- } \\
\text { şüncesi varsa çok önemlidir. }\end{array}$ & 2 & 12,5 & $\begin{array}{l}\text { Keman çalmak için fiziksel bir } \\
\text { ayrıcalık gerekmez, çalışma ve } \\
\text { azimle her şey düzelir. }\end{array}$ & 1 & & 11,1 \\
\hline \multirow{2}{*}{$\begin{array}{l}\text { Öğrencinin bireysel çalgı çalışma- } \\
\text { ları esnasında gelişim kaydedebil- } \\
\text { mesi adına işitsel yeteneklerinin } \\
\text { kuvvetli olması önemlidir. }\end{array}$} & 1 & 6,2 & Herkes keman çalabilir. & 1 & & 11,1 \\
\hline & & & \multicolumn{2}{|l|}{$\begin{array}{l}\text { Fiziksel sorunlar esneme hareket- } \\
\text { leri ile, işitsel sorunlar ise bantlar } \\
\text { yardımıla çözülebilir. }\end{array}$} & 1 & 11,1 \\
\hline
\end{tabular}

Tablo 5'e baktığımızda öğretmenlerin büyük bir kısmının kemanın perdesiz bir çalgı olması nedeniyle işitsel yetenekleri yeterli olmayan öğrencilerin ilerleme kaydedemeyeceğini, bu nedenle keman çalmak için ge- 
rekli fiziksel ve işitsel özelliklere sahip olma durumunun önemli olduğunu düşündüğü görülmektedir. Buna ek olarak öğretmenler fiziksel özellikleri keman çalmak için yetersiz olan öğrencilerin çalgıdaki gelişiminin ve başarısının olumsuz anlamda etkileneceğini, öğrencinin ilerde mesleki bir düşüncesi varsa fiziksel ve işitsel özelliklere sahip olma durumunun çok önemli olduğunu ve öğrencinin bireysel çalgı çalışmaları esnasında gelişim kaydedebilmesi adına işitsel yeteneklerinin kuvvetli olmasının önemli olduğunu dile getirmiştir.

Keman çalmak için gerekli fiziksel ve işitsel özelliklere sahip olma durumunun önemsiz olduğunu düşünen öğretmenlerin büyük bir kısmı, öğrencinin istekli olmasının daha önemli olduğu görüşünü dile getirmiştir. Bunlara ek olarak hobi olarak devam ettirilen keman eğitiminde işitsel ve fiziksel özelliklerin önemli olmadığı, keman çalmak için fiziksel bir ayrıcalık gerekmediği, çalışma ve azimle her şeyin düzeleceği, herkesin keman çalabileceği ve fiziksel sorunların esneme hareketleri ile, işitsel sorunların ise bantlar yardımıyla çözülebileceğine ilişkin görüşler de dile getirilmiştir.

Öğrenci ve ebeveynler tarafından hiçbir mesleki amaç güdülmese dahi, öğrencinin çalgı eğitimi sürecinden keyif alabilmesi ve karşılaştığ 1 teknik zorlukları hayal kırıklığına uğramadan, düzenli bireysel çalışmalarla kısa sürede yenebilmesi adına bazı fiziksel ve işitsel özelliklere sahip olmanın oldukça önemli olduğu düşünülmektedir. Özengen müzik eğitimi kurumunda çalg1 eğitimi alan öğrencilerin bu eğitimi hobi olarak sürdürdüklerini düşünen öğretmenler, fiziksel ve işitsel özelliklerin önemli olmadığ1 görüşünü dile getirmiştir ancak bu durum özengen müzik eğitimi kurumlarının mesleki müzik eğitimine hazırlayıcı rolü açısından oldukça düşündürücüdür.

Ö-15: "Keman çalmak için fiziksel ve işitsel özelliklerin yeterli olması çok önemlidir fakat özengen müzik eğitimi kurumlarında ne yazık ki çocukların yetenekleri ikinci plana atılıyor, ticari kaygı nedeniyle fiziksel ve işitsel özellikleri yetersiz olan öğrenciler kuruma kabul ediliyor ve öğrencimiz oluyor."

Ö-20: "Keman çalan bir bireyin kesinlikle çok iyi işitmesi gerekir." 
Tablo 6. Ö ̆̆retmenlere göre öğrencilerin çalgı tercihlerini etkileyen faktörler

\begin{tabular}{lll}
\hline Görüsşler & $\mathbf{f}$ & $\mathbf{\%}$ \\
\hline Çevresindeki bireylerden etkilenme ve özenme & 10 & 33,5 \\
Çalgının popülaritesi nedeniyle & 7 & 23,2 \\
Çalgının tınısı nedeniyle & 6 & 19,9 \\
Sosyal medya yoluyla & 4 & 13,3 \\
Ebeveyn istekleri nedeniyle & 2 & 6,7 \\
Çalgının taşıma kolaylı̆̆ı nedeniyle & 1 & 3,4 \\
\hline
\end{tabular}

Tablo 6'da görüldü̆̆̈ü üzere öğretmenlerin çoğunluğu öğrencilerin çevresindeki bireylerden etkilenerek ve özenerek ya da çalgının popülaritesi nedeniyle çalgı tercihi yaptığını ifade etmiştir. Tablodaki bulgulardan öğrencilerin büyük bir kısmının çalgı tercihini kendi yaptığı sonucu çıarılabilir. Öğrencinin çalgı eğitimini severek ve isteyerek sürdürmesi, başarılı olabilmenin ilk adımı olduğundan öğrencilerin çalgı seçimini kendilerinin yapması olumlu bir durumdur.

Ö-2: “Çevre önemli bir etken. Çoğu öğrenci arkadaşının çaldığı çalgıya göre seçim yapıyor."

Ö-6: "Çо̆̆u öğrenci aileleri tarafından hobi amaçlı yönlendiriliyor."

Ö-18: "Sosyal medya artık çok yaygınlaştı̆̆ i için tercihler genellikle internet ortamında gördükleri kişilere özenerek oluyor."

Tablo 7. Öğretmenlere göre keman eğitimine başlamadan önce başka bir çalgı çalmanın ya da müzikle farklı etkileşimler içinde bulunmuş olmanın keman eğitimi sürecine etkileri

\begin{tabular}{lll}
\hline Görüşler & f & $\%$ \\
\hline Öğrencinin notayı algılama hızının daha yüksek olması & 7 & 28 \\
Daha az entonasyon problemi yaşanması & 5 & 20 \\
Daha hızlı ilerleme kaydedilmesi & 5 & 20 \\
Böyle bir öğrencim yok & 5 & 20 \\
Öğgrencinin hazırbulunuşluk durumunun daha iyi olması & 2 & 8 \\
Öğrencinin teori bilgisinin daha kuvvetli olması & 1 & 4 \\
\hline
\end{tabular}

Tablo 7'ye göre öğretmenlerin büyük bir kısmı keman eğitimine başlamadan önce başka bir çalgı çalan ya da müzikle farklı etkileşimler içerisinde bulunmuş olan öğrenciler ile çalışmıştır. Keman eğitimine başlamadan önce başka bir çalgı çalan ya da müzikle farklı etkileşimler içerisinde bulunmuş olan öğrenciler ile çalışan öğretmenlerin çoğu, öğrencilerin notayı algılama hızlarının daha yüksek olduğunu dile getirmiştir. Buna ek olarak öğrencilerin daha az entonasyon problemi yaşadığına, daha hızlı 
ilerleme kaydedildiğine ve öğrencinin hazırbulunuşluk durumun daha iyi olduğuna ilişkin görüşler de ifade edilmiştir.

Keman eğitimi öncesinde başka bir çalgı çalmış ya da müzikle farklı etkileşimler içinde bulunmuş olan öğrenciler, keman eğitimi sürecinde karşılaşacakları durumlara hazırlıklı olduklarından daha bilinçli bir şekilde eğitime başlamakta ve olası zorlukları göze almaktadırlar. Öte yandan müzik ile ilk etkileşimine keman eğitimi ile başlayan bazı öğrencilerin, çalgı çalmanın onların düşündüklerinden daha zor olması, yoğun emek ve fedakârlıklar gerektirmesi, sabır isteyen uzun bir süreç olması gibi sebeplerle hayal kırıklığına uğrayabileceği ve keman eğitimi süreçlerinin kısa ömürlü olabileceği düşünülmektedir.

Ö-3: "Daha önce piyano eğitimi almış olan bir öğrencim diğer öğrencilerime göre daha az entonasyon problemi yaşamaktadır."

Ö-19: "Daha önce farklı bir müzik aleti çalmış kişi kemana daha çabuk adapte oluyor, sol elini daha rahat kullanıyor ve notaları okumakta zorluk çekmiyor."

Tablo 8. Öğretmenlere göre öğrencilerin keman eğitimi almasındaki genel amaçları ve hedefleri

\begin{tabular}{lll}
\hline Görüşler & f & $\%$ \\
\hline Hobi amacı ile & 13 & 46,5 \\
Meslek edinme amacı ile & 7 & 25 \\
Popüler parçaları çalabilme amacı ile & 6 & 21,4 \\
Konser ve etkinliklere aktif katılımcı olma amacı ile & 2 & 7,1 \\
\hline
\end{tabular}

Tablo 8'e göre öğretmenlerin büyük bir kısmı öğrencilerin hobi amac1 ile çalg1 eğitimlerini sürdürdügünü ifade etmiştir. Öğretmenlerin neredeyse yarısının, öğrencilerin hobi amacı ile keman eğitimi aldığını belirtmesi özengen müzik eğitimi kurumları için şaşırtıcı bir sonuç olmamakla birlikte, öğretmenlerin dörtte birinin öğrencilerin meslek edinme amacı ile keman eğitimi aldığı görüşünü dile getirmesi, özengen müzik eğitiminin mesleki müzik eğitimine hazırlayıcı rolünü kanıtlar niteliktedir.

Ö-9: “Çoğu öğrenci hobi olarak bu eğitimi sürdürüyor fakat profesyonel anlamda ilerlemek isteyen öğrencilerim de var."

Ö-16: "Kurumda bir konser ya da etkinlik yapılıyorsa bunlara aktif olarak katulabilmek için derslere gelen öğrenciler var."

Ö-17: "Bu zamana kadar bu işi meslek edinmek isteyen öğrencim hiç olmadı." 
Tablo 9. Öğretmenlere göre öğrencilerin ders dışında çalgıları üzerinde çalışma yapma durumları

\begin{tabular}{|c|c|c|c|c|c|}
\hline Çalışmaları yeterlidir & $\mathrm{f}$ & $\%$ & $\begin{array}{l}\text { Çalışmaları yeterli değil- } \\
\text { dir }\end{array}$ & $f$ & $\%$ \\
\hline $\begin{array}{l}\text { Öğrenciler verilen etüt ve } \\
\text { eserlerin tekrarını düzenli } \\
\text { olarak yaparlar }\end{array}$ & 3 & 12 & $\begin{array}{l}\text { Öğrencilerin örgün eğitim } \\
\text { gördükleri okulları ve ev } \\
\text { ödevleri çok vakit aldığın- } \\
\text { dan keman çalış̧alarına } \\
\text { gereken zamanı ayıramı- } \\
\text { yorlar. }\end{array}$ & 6 & 24 \\
\hline $\begin{array}{l}\text { İlk dersten her gün çalgı ça- } \\
\text { lışma şartı koyarım aksi tak- } \\
\text { dirde derslere devam etmem. }\end{array}$ & 2 & 8 & $\begin{array}{l}\text { Öğrencilerin çok büyük ço- } \\
\text { ğunluğu yeteri kadar çalgı } \\
\text { çalışmıyor. }\end{array}$ & 6 & 24 \\
\hline $\begin{array}{l}\text { Hobi amaçlı olduğu için yap- } \\
\text { tıkları çalışma yeterlidir. }\end{array}$ & 2 & 8 & $\begin{array}{l}\text { Öğrenciler yalnızca dersten } \\
\text { bir gün önce keman çalışı- } \\
\text { yor. }\end{array}$ & 2 & 8 \\
\hline \multirow[t]{2}{*}{$\begin{array}{l}\text { Öğrencileri zaten çok zorla- } \\
\text { madığımız için yeterlidir. }\end{array}$} & 1 & 4 & $\begin{array}{l}\text { Öğrenciler sadece dersten } \\
\text { derse keman çalışıyor. }\end{array}$ & 2 & 8 \\
\hline & & & $\begin{array}{l}\text { Öğrenciler keman dersini } \\
\text { hobi olarak gördükleri için } \\
\text { yeterince ciddiye almıyor } \\
\text { ve çalgı calışmyor. }\end{array}$ & 1 & 4 \\
\hline Toplam & 8 & 32 & & 17 & 68 \\
\hline
\end{tabular}

Tablo 9' da görüldüğü üzere öğretmenlerin büyük bir kısmı öğrencilerin ders dışında çalgıları üzerinde yaptığı çalışmaların yeterli olmadığını dile getirmiştir. Çalgı çalmanın gereklilikleri göz önünde bulundurulduğunda, öğretmenlerin oldukça büyük bir kısmının öğrencilerinin çalgıları üzerinde yeterli çalışma yapmadıklarını ifade etmesi fazlasıyla düşündürücüdür.

Bir çalgıda gelişim kaydedebilmek için gereken en önemli hususlardan biri, öğretmensiz yapılan ders dışı çalgı çalışmalarıdır. Hangi çalgı olursa olsun, becerilerini geliştirmek isteyen her çalg1 öğrencisi, düzenli olarak öğretmensiz ders dışı çalgı çalışması yapmalıdır. Öğretmenlerin dörtte birinin öğrencilerin örgün eğitim gördükleri okulları ve ev ödevleri çok vakit aldığı için keman çalışmalarına gereken zamanı ayıramadıklarını belirtmesi ise oldukça dikkat çekicidir.

Ö-8: "İtiraf etmeliyim ki ders dışında düzenli olarak çalgı çalışan bir ya da iki öğrencim var. Geri kalan öğrencilerim maalesef sadece dersten derse kemanı eline alıyor. O yüzden asla yeterli değil." 
Ö-10: “Öğrencilerin örgün eğitimlerine devam ettikleri okulları ve ödevleri hafta içi çok zamanlarını alıyor, düzenli-planlı çalışma sistemleri de olmadığından öğrenciler keman egzersizlerine yeteri kadar zaman ayıramıyorlar. Maalesef yaptıkları bireysel çalışmalar yeterli değildir."

Ö-13: "Öğrencinin kaydını alırken günde en az 1 saat bireysel çalışma şartı koyuyorum. Çalışmayan öğrencilere karşı biraz sertiz, dersi bitirmek ile tehdit ederiz. Başta böyle bir tavır ortaya koyduğumuz için öğrenciler çalışmamaya cesaret edemiyor. Düzenli çalışmalarının faydaların hem öğrenciler hem de biz görüyoruz, derslerimiz akıcı oluyor."

Ö-18: "Ne yazık ki yeterli değil. Birçok öğrenci bu işi hobi olarak devam ettirdiği için ders olarak değil ĕ̆lence olarak görüyor. Bu durumda çalgı çalışmaya ayrllan süreyi etkiliyor ve bu sürenin az olması öğrencinin yavaş ilerlemesine ve potansiyelini kullanamamasına neden oluyor. Öğrenci okuldaki diğger derslerine daha fazla vakit ayırdığı için çalgı çalışmaya yeterince vakit bulamıyor. Bir de fiziksel güç gerektiren bir aktivite olduğu için bazı öğrencilerin üşendiğini düşünüyorum. Keman kutusunu açmaya bile üşenen öğrencim var."

Tablo 10. Öğretmenlere göre öğrencilerin derslere düzenli olarak katılma durumu

\begin{tabular}{lll}
\hline Görüşler & f & \% \\
\hline $\begin{array}{l}\text { Düzenli olarak katılıyorlar } \\
\begin{array}{l}\text { Düzenli olarak katılamıyorlar (Sağlık sorunları, sınavlar, şehir dışı seya- } \\
\text { hatleri, diğer aktiviteler) }\end{array}\end{array}$ & $\begin{array}{l}24 \\
\text { Toplam }\end{array}$ & 46 \\
\hline
\end{tabular}

Tabloda görüldüğü üzere öğretmenlerin neredeyse tamamı öğrencilerin derslere düzenli olarak katıldıklarını ifade etmiştir. Öğrencilerin derslere düzenli olarak katılamama sebepleri arasında ise sağlık sorunları, s1navlar, şehir dışı seyahatleri ve diğer aktiviteler belirtilmiştir.

Çalg1 eğitimi sürecinde derse düzenli olarak katılım gösteren öğrencilerin, beceri gelişimleri öğretmen tarafından düzenli olarak takip edilir ve öğrenci geri dönütler alır. Bu geri dönütler sayesinde bireysel çalgı çalışmalarına yön veren öğrencinin motivasyonunu kaybetmemesi ve bireysel çalgı çalışma alışkanlıklarını sürdürebilmesi adına çalgı derslerine düzenli olarak katılımı oldukça önem arz etmektedir. Bu nedenle öğretmenlerin neredeyse tamamının öğrencilerin derse düzenli olarak katıldığını belirtmesi olumlu bir durum olarak değerlendirilebilir. 
Ö-5: "Zor geldiği için katılmayabiliyorlar. Elim acıdı, kolum ağrıdı, yoruldum gibi pes etmeler görülüyor."

Ö-13: "Düzenli olarak katıllyorlar fakat çoğu öğrenci özel okullarda örgün eğitimine devam ettiği için hafta sonu sinavları oluyor, o zamanlar derse katılamiyorlar."

Ö-21: "Kurumumuzda öğrenciler okul gibi aynı gün ayn saatte gelmek zorunda, düzenli katılmama gibi bir durum söz konusu olamaz."

Tablo 11. Öğretmenlere göre öğrencilerin keman eğitimini bırakma sebepleri

\begin{tabular}{lll}
\hline Görüşler & f & \% \\
\hline Liseye-üniversiteye giriş sınavı hazırlıkları & 7 & 22,5 \\
Maddi sebepler & 5 & 16,1 \\
Bireysel çalgı çalışmaya vakit bulamama & 4 & 13 \\
Bir çalgı öğrenme disiplininin zor gelmesi & 4 & 13 \\
Şehir dışına taşınma & 4 & 13 \\
Örgün eğitim kurumlarının yoğunluğu & 3 & 9,6 \\
Keman eğitimini bırakan öğrencim olmadı & 3 & 9,6 \\
Evlilik & 1 & 3,2 \\
\hline
\end{tabular}

Tabloda görüldüğü üzere öğretmenlerin büyük bir kısmı keman eğitimini bırakan öğrenciler ile karşılaşmıştır. Öğretmenlerin birçoğu, öğrencilerin liseye-üniversiteye giriş sınavı hazırlıkları ya da maddi sebepler nedeniyle eğitimini bıraktığını ifade etmiştir. Günümüzdeki sınav sistemi nedeniyle adeta bir yarış ortamında olan öğrencilerin liseye-üniversiteye giriş sınavı hazırlıkları esnasında özengen müzik eğitimi kurumlarında çalgı eğitimlerini bırakması ne yazık ki şaşırtıcı bir sonuç değildir.

Ö-14: "Genellikle lise ve üniversite giriş stnavlarna hazırlı döneminde olan öğrenciler keman dersini birakmak zorunda kalıyor."

Ö-25: "Bu disiplin zor geldiği için bırakıyorlar."

Ö-5: "Öğrenciler okul yoğunluğundan ötürü dersleri bırakabiliyorlar." 
Tablo 12. Öğretmenlere göre öğrencilerin çalgı çalmaya karşı ilgi ve hevesleri

\begin{tabular}{lll}
\hline Görüşler & f & \% \\
\hline Çok ilgili ve hevesliler & 9 & 36 \\
Başta çok ilgili ve hevesliler, zamanla pes ediyorlar & 4 & 16 \\
Genellikle ilgililer & 4 & 16 \\
İlgililer fakat çalışmadan başarmak istiyorlar & 3 & 12 \\
İlgi ve heves düzeyi öğretmen ile alakalıdır & 3 & 12 \\
İlgi yaşa göre değişiyor & 1 & 4 \\
İlgili değiller & 1 & 4 \\
Toplam & 25 & 100 \\
\hline
\end{tabular}

Tablo 12'de görüldüğü üzere öğretmenlerin çoğu kısmen de olsa öğrencilerin çalgı çalmaya karşı ilgili ve hevesli olduklarını dile getirmiştir.

Çalg1 eğitimi sürecinde öğrencinin çalgısı ile bolca vakit geçirmesi beklendiğinden, öğretmenlerin büyük bir kısmının öğrencilerin keman çalmaya karşı ilgi ve heveslerinin olduğunu belirtmesi olumlu bir durum olarak değerlendirilebilir. Öğretmenlerin dörtte birinin öğrencilerin ilgili olduğunu fakat çalışmadan başarmak istediklerini ve başta çok ilgili ve hevesli olan öğrencilerin zamanla pes ettiğini belirtmesinin ise, öğrencilerin çalgı çalmanın gereklilikleri konusunda yeterli bilgiye sahip olmadan çalgı eğitimine başlaması ile ilgili olduğu düşünülebilir.

Ö-2: “Çoğu öğrencim ilgili ve dersten keyif alıyorlar, bu durumda kendi istekleri ve merakları doğrultusunda derslere başlamalarının büyük etkisi var. Öğrenmekten keyif alan öğrenciler ile çalışıyorum."

Ö-7: "Illk başta ilgililer ancak seviye zorlaştıkça pes etmeye meyilliler."

Ö-15: "Ne yazık ki öğrencilerin çalgı çalmaya karşı bir ilgisi ya da hevesi yok. Keman dersi almak onlar için bir hayal iken, o hayale ulaşınca bütün hevesleri kaçıyor. Derslere büyük umutlar ve hayallerle başlıyorlar, fakat disiplini ve zoru görünce maalesef bütün heves bitiyor."

\section{İkinci Alt Probleme İlişkin Bulgular ve Yorumlar}

Tablo 13. Öğretmenlere göre düzenli olarak konser etkinlikleri yapılmasının öğrenci üzerindeki etkileri

\begin{tabular}{lll}
\hline Görüşler & f & \% \\
\hline Öğrencilerin motivasyonu artıyor & 11 & 40,7 \\
Öğrenciler çalgı üzerinde daha çok çalışma yapıyor & 6 & 22,2 \\
Kurumda düzenli olarak konser etkinlikleri yapılmıyor & 4 & 14,8 \\
Kalabalık karşısına çıkmak ve hata yapma korkusu öğrencileri tedirgin ediyor & 3 & 11,1 \\
Öğrencinin özgüveni artıyor & 2 & 7,4 \\
Öğrenciler kendilerini ifade etmeyi öğreniyorlar & 1 & 3,8 \\
\hline
\end{tabular}


Tablo 13'e göre öğretmenlerin büyük bir kısmının çalıştığı kurumda düzenli olarak konser etkinlikleri yapılmaktadır. Öğretmenlerin çoğu, düzenli olarak yapılan konser etkinliklerinin öğrencilerin motivasyonunu artırdığını ifade etmiştir. Bu ifadeyi azalan bir değer içerisinde "öğrenciler çalgı üzerinde daha çok çalışma yapıyor, kalabalık karşısına çıkmak ve hata yapma korkusu öğrencileri tedirgin ediyor" ifadeleri takip etmektedir.

Öğrencinin kazandığı becerileri sergileme imkânı bulması ve bu sayede çevresinden takdir görmesinin, çalgı çalmaya karşı ilgisini, hevesini ve motivasyonunu artıracağı göz önünde bulundurulduğunda, öğretmenlerin büyük bir kısmının görev yaptığı kurumda düzenli olarak konser etkinlikleri yapılması olumlu bir durum olarak değerlendirilebilir.

Düzenli olarak konser etkinlikleri yapılmasının öğrenci üzerinde birçok olumlu etkisi vardır. Öğrencinin sahne deneyimini tatması, çalgısına verdiği emeklerin karşılığını aldığını hissettirir ve öğrencinin motivasyonunu artırabilir. Bununla birlikte ebeveynler konserler sayesinde çocuklarındaki gelişimi canlı olarak görme fırsatına sahip olurlar ve bu sayede çocuklarını çalgı eğitimi alanında desteklemeye devam edebilirler.

Ö-2: "Sahne deneyimi sayesinde motivasyonu artan ve daha sıkı çalışan öğrencilerim var."

Ö-15: “Bazı öğrenciler kalabalık karşısında çalacağı için strese kapılıyor. Kalabalık bir topluluk karşısına çıkmak ve hata yapma korkusu onları tedirgin ediyor."

Ö-22: "Konserler sayesinde öğrencilerin motivasyonu ve özgüveni artıyor, yaptıkları işi daha da önemsemeye başlıyorlar."

Tablo 14. Öğretmenlere göre öğrencilerin kurum tarafından kent içerisindeki sanatsal faaliyetlere yönlendirilmesinin öğrenci üzerindeki etkileri

\begin{tabular}{lll} 
Görüşler & $\mathbf{f}$ & $\mathbf{\%}$ \\
\hline Küum sanatsal faaliyetlere yönlendirmiyor & 12 & 48 \\
Öğrenci üzerinde olumlu birçok etkisi vardır & 7 & 28 \\
Öğrenciler yorum yapmayı öğreniyor & 2 & 8 \\
Öğrenciler sahnede nasıl davranılması gerektiğini öğreniyor & 1 & 4 \\
Öğrencilerin motivasyonu artıyor & 1 & 4 \\
Öğrenciler farklı bir bakış açısı kazanıyor & 1 & 4 \\
Öğrenciler çalgılarına daha hevesli çalışıyor & 1 & 4 \\
\hline
\end{tabular}


Tablo 14'te görüldüğü üzere öğretmenlerin çoğunluğu, kurumlarının öğrencileri kent içerisindeki sanatsal faaliyetlere yönlendirmediği görüşündedir. Öğretmenlerin yarısının görev yaptığı kurum öğrencileri kent içerisindeki sanatsal faaliyetlere yönlendirirken, diğer yarısının yönlendirmemesi ise düşündürücüdür. Çalg1 eğitimi alan öğrencilerin kent içerisindeki sanatsal faaliyetlere katılımı pek çok yönden önem arz etmektedir. Müzikle amatör olarak ilgilenen öğrencilerin ve ebeveynlerinin bu işi profesyonel olarak yürüten kişileri dinlemesi ve izlemesi, bireylerin kültürlenmesi ve bilinçlenmesi açısından oldukça önemlidir. Bu nedenle kent içerisindeki sanatsal faaliyetlerin düzenli olarak takip edilmesi ve bu faaliyetlere katılım sağlanması gerektiği düşünülmektedir.

Ö-19: "Bu etkinlikler sayesinde öğrenciler sahnede nasıl davranmaları gerektiğ̈ini ve heyecanlarını nasıl kontrol edeceklerini öğreniyor."

Ö-23: "İstanbul'da yaşadığımız için bu konuda çok fazla seçeneğimiz oluyor ve bu durumun olumlu etkilerini de gözlemliyoruz elbette."

Tablo 15. Öğretmenlere göre kurumlarında keman eğitimini destekleyici derslere ilgi ve katılım düzeyinin durumu

\begin{tabular}{lll}
\hline Görüşler & $\mathbf{f}$ & $\mathbf{\%}$ \\
\hline Kurumda keman eğitimini destekleyici dersler verilmiyor & 11 & 44 \\
İlgi ve katılım düzeyi yüksek & 5 & 20 \\
Mesleki hedefi olan öğrenciler ile sınırlı kalıyor & 4 & 16 \\
Zaman darlığı ve maddi nedenlerden ötürü katılım oldukça düşük & 3 & 12 \\
İlgi ve katılım düzeyi düşük & 2 & 8 \\
\hline
\end{tabular}

Tablo 15'te görüldüğü üzere öğretmenlerin büyük bir çoğunluğu, kurumlarında keman eğitimini destekleyici derslerin verilmediğini dile getirmiştir.

Kemanın perdesiz bir çalgı olması nedeniyle işitme becerilerinin geliştirilmesinin oldukça önemli olduğu keman eğitimi sürecinde, öğrencinin işitme eğitimi ile desteklenmesinin oldukça faydalı olacağı düşünülmektedir. Öğretmenlerin yarısının çalıştığı kurumda keman eğitimini destekleyici derslerin verildiğini belirtmesine rağmen, bu derslere katılım oranının oldukça düşük olduğunu belirten öğretmen sayısının araştırma grubunun beşte üçünden fazlasını oluşturması düşündürücüdür.

Ö-2: “Bu dersler sadece güzel sanatlar eğitimi almak isteyen öğrencilerle stnırlı kalıyor. Keman öğrencileri tarafindan hiç tercih edilmedi." 
Ö-5: "Kurumumuzda bu tarz dersler verilmiyor fakat biz bu desteği ders içerisinde sağlamaya çalışıyoruz. Teoriye yönelik çalışmalar yapıyoruz."

Ö-18: "Kurumumuzda keman eğitimini destekleyici dersler veriliyor fakat biz öğretmenler bu derslerin çalgı dersinin yanında ne kadar gerekli olduğunu söylesek de veliler tarafından sicak bakılmıyor. Öğrencilerin derslere ilgisi olsa dahi maddi durumdan kaynaklı çok ilgi olmadığını düşünüyorum ve bu bana göre bir problem."

Tablo 16. Öğretmenlere göre dïzenli olarak birlikte çalgı çalınan toplu derslerin öğrenci üzerindeki etkileri

\begin{tabular}{lll}
\hline Görüşler & f & $\%$ \\
\hline Kurumda düzenli olarak birlikte çalgı çalınan toplu ders yok & 18 & 72 \\
Öğrencilerin birlikte çalma becerileri gelişir & 2 & 8 \\
Öğrencilerin işitme becerileri gelişir & 2 & 8 \\
Öğrencilerin bireysel çalgı çalışmaları artar & 2 & 8 \\
Öğrenciler görev bilinci kazanır & 1 & 4 \\
\hline
\end{tabular}

Tabloda görüldüğü üzere öğretmenlerin oldukça büyük bir kısmı çalıştıkları kurumda düzenli olarak birlikte çalgı çalınan bir toplu ders olmadığını dile getirmiştir. Öğretmenlerin dörtte üçünün çalıştığı kurumda düzenli olarak birlikte çalgı çalınan toplu bir ders olmadığını belirtmesi birlikte çalmanın faydaları düşünüldüğünde fazlasıyla dikkat çekicidir. Kurumlarında düzenli olarak birlikte çalgı çalınan bir toplu ders olduğunu ifade eden az sayıdaki öğretmen ise bu durumun faydaları ile ilgili olarak "öğrencilerin birlikte çalma ve işitme becerilerinin geliştiği, öğrencilerin bireysel çalgı çalışmalarının arttığı ve öğrencilerin görev bilinci kazandığı" görüşlerini ifade etmiştir.

Birlikte çalgı çalmak müzikal faydalarının yanı sıra oldukça keyifli bir aktivitedir. Düzenli olarak birlikte çalgı çalınan toplu dersler sayesinde öğrencilerin motivasyonunun artacağı, daha çok çalg1 çalışacağı, birlikte çalma becerilerinin gelişeceği düşünülmekle birlikte, sosyalleşen öğrencilerin iletişim becerilerinin de gelişeceği göz önünde bulundurulmalıdır.

Ö-13: “Bu ders sayesinde öncelikle öğrencide birlikte hareket etme duygusu gelişiyor. Sandalyelerin ya da nota sehpalarının düzeni bile öğrenciye düzenli yaşamayı öğretiyor. Öğrenciye görev bilinci kazandırıyor."

Ö-21: "Öğrenciler çoksesli duyumların geliştiriyor, bir bütünün parçası olmak ve topluca bir iş başarmak gibi duyguları tadıyor." 
Ö-25: "Orkestra dersi sayesinde öğrenci kesinlikle daha çok çalgı çalışıyor ve bunun sayesinde de seviyesi hılıca yükseliyor."

Tablo 17. Öğretmenlerin çalıştığı kurumda ders öğretim programının belirlenme şekli

\begin{tabular}{lll}
\hline Görüşler & f & \% \\
\hline Öğretmen tarafından & 10 & 40 \\
MEB ve Kurum yönetimi ortak kararı ile & 4 & 16 \\
MEB tarafından & 3 & 12 \\
Belirli bir program olmadan & 3 & 12 \\
Bilmiyorum & 3 & 12 \\
Öğretmen ve kurum yönetimi ortak kararı ile & 1 & 4 \\
Kurum yönetimi tarafından & 1 & 4 \\
Toplam & 25 & 100 \\
\hline
\end{tabular}

Tabloda görüldüğü üzere araştırma grubuna dâhil edilen öğretmenlerin tamamının çalıştığı kurum MEB'e bağlı olmasına rağmen, yalnızca dörtte birinin ders öğretim programının MEB tarafından ya da MEB-Kurum yönetimi ortak kararı ile belirlendiğini ifade etmesi fazlasıyla dikkat çekicidir. Ders öğretim programının belirlenme şeklini bilmeyen ve herhangi bir ders öğretim programı olmadığını belirten öğretmenler yine araştırma grubunun dörtte birini oluşturmaktadır. Öğretmenlerin büyük bir kısmı ders öğretim programını kendilerinin belirdiğini ifade etmiştir. Bu durumun aynı kurum çatısı altında çalgı eğitimi alan öğrencilerde dahi seviye anlamında ciddi farklılıklara yol açabileceği düşünülmektedir.

Ö-16: "Herhangi bir program yok."

Ö-24: “Çalıştığım kurum MEB denetiminde bir kurs yeri. Öğrenci eğger sertifika almak isterse MEB programına göre eğitim alıyor. Diğer öğrencilerin programı öğretmen tarafindan belirleniyor."

Ö-25: "Ders öğretim programı kurum yönetimi ve MEB ortak kararı ile belirlenir."

Tablo 18. Öğretmenlerin görev yaptıkları kurumun çalışma şartlarına yönelik değerlendirmeleri

\begin{tabular}{lll} 
Görüşler & $\mathbf{f}$ & \% \\
\hline Oldukça olumlu & 11 & 30,5 \\
Art arda çok fazla derse girmemiz gerekiyor & 4 & 11 \\
Ders arası yok & 3 & 8,4 \\
Yemek aramız yok & 3 & 8,4 \\
Öğretmenler odası yok & 2 & 5,5 \\
Ders ücretleri çok az & 2 & 5,5 \\
Geç saatlere kadar çalışma zorunluluğumuz var & 2 & 5,5 \\
Derslikler çok küçük & 1 & 2,8
\end{tabular}


Dersliklerde havalandırma yetersiz

Ders olmasa dahi kurumda bulunmak zorundayız

Tablo 18'e göre öğretmenlerin yaklaşık olarak üçte biri kurumdaki çalışma şartlarını gayet olumlu olarak değerlendirirken, üçte ikisinin olumsuz değerlendirmeler yapması bu kurumlardaki işleyiş açısından düşündürücüdür. Ayrıca art arda çok fazla derse girilmesi gerektiğini, ders arası ve yemek arası olmadığını belirten öğretmenlerin araştırma grubunun dörtte birini oluşturduğu görülmektedir. Bu durumun özel kurumlarda kurum yönetiminin ticari beklentileri doğrultusunda, öğretmenlerin dersyemek arası olmadan çok yoğun ve uzun saatler çalışmak zorunda bırakılması nedeniyle olabileceği düşünülmektedir.

Ö-2: "Çalışma şartlarım gayet güzel ve rahat. Sıcak bir aile ortamı ile çalışıyorum."

Ö-10: "Dersliklerimiz çok küçük ve havalandırma yetersiz."

Ö-15: "Derslere sabah 10'da başlıyorum ve akşam 6 'da çıkıyorum. En son ders saatinde gelen keman öğrencime ne kadar faydalı olabildiğim tartışılı çünkü mola vaktimiz de olmadığı için tüm gün çok yoruluyorum. Bu durum verimimi düşürüyor. Yemek aramız da yok, ders içerisinde bir şeyler atıştırmaya çalışıyoruz. Nefes alacak vaktimiz yok."

Ö-16: "Kendimize ayıracak zamanımız olmuyor, çok yoğun çalıştı̆̆ımız için en büyük sıkıntımız zaman. Bazen kurum çok sıcak ya da soğuk oluyor. Genellikle yemek aramız yok. Kurumdan birkaç günlüğ̈̈ne izin almak da problem, veliler ücretlerini tam ve zamanında ödemediğinde bizde ödeme alamıyoruz ne yazık ki."

Tablo 19.Öğretmenlerin ders saatlerinin belirlenme şekli ve ders programlarından memnun olma durumları

\begin{tabular}{lll} 
Görüşler & f & $\mathbf{\%}$ \\
\hline Veli ve öğretmen ortak kararı ile belirlenir, memnunum. & 10 & 40 \\
Ders saatlerimi kendim belirlediğim için memnunum. & 7 & 28 \\
Memnun değilim. & 4 & 16 \\
Kurum yönetimi belirlediği için memnun değilim. & 3 & 12 \\
Kurum yönetimi ve öğretmen ortak kararı ile, memnunum. & 1 & 4 \\
Toplam & 25 & 100 \\
\hline
\end{tabular}


Tabloya bakıldığında öğretmenlerin büyük bir kısmının ders programından memnun olduğunu ifade ettiği görülmektedir. Öğretmenlerin büyük bir kısmının ders programından memnun olduğunu belirtmesinin, özel kurumlarda ders programlarını kendi yaşantılarına göre düzenleyebilmeleri nedeniyle olduğu düşünülmektedir. Öğretmenlerin dörtte birinden fazlası ders programından memnun değildir, bu durumunda özel kurumlarda kamu kurumlarına göre daha uzun süreli ve geç saatlere kadar çalışılması nedeniyle olabileceği düşünülmektedir.

Ö-13: "Ders programımı kendim belirlediğim için memnunum."

Ö-18: "Ders programı esasında öğretmene göre planlanıyor. Haftada bir gün tatil ve diğer 6 günde dersler 10-11 saat, bazen ö̆gretmen kendini zorlarsa günde 13-14 saate kadar çıkabiliyor. Bu durum hem öğretmen hem de öğrenci için faydalı değil. Günde ortalama 8-9 saat ders ideal olabilir. Ayrıca günde bir saat öğretmenin kendine vakit ayırabileceği ve yemek ihtiyacını giderebileceği bir boşluk yaratılması gerektiğini düşünüyorum. Fakat özel bir kurum olduğu için sonuçta bir yönetici var ve ne derse onu yapmak durumundasını.."

Ö-20: "Ders saatlerimizi patronumuz belirliyor. O nasıl isterse ona göre plan yapıyoruz. Ders programımdan memnun değilim."

\section{Üçüncü Alt Probleme İlişkin Bulgular ve Yorumlar}

Tablo 20. Öğretmenlere göre ailelerin müzik eğitimi veya çalgı çalmanın gereklilikleri gibi konularda öğrenciye yeterli desteği ve motivasyonu sağlama durumu

\begin{tabular}{lll}
\hline Görüşler & f & $\%$ \\
\hline Genellikle sağllyor & 13 & 52 \\
Bazı aileler sağllyor, bazıları sağlamıyor & 8 & 32 \\
Sağlamıyor & 4 & 16 \\
Toplam & 25 & 100 \\
\hline
\end{tabular}

Tablo 20'ye göre öğretmenlerin çoğunluğu ailelerin müzik eğitimi veya çalgı çalmanın gereklilikleri gibi konularda öğrenciye yeterli desteği ve motivasyonu sağladığını dile getirmiştir.

Çalg1 eğitimi sürecinde ailelerin özellikle küçük yaş grubu öğrencilere destek olması ve motivasyon sağlaması pek çok açıdan önemlidir. Ailenin de çalg1 eğitimi sürecine dâhil olması, öğretmenin verdiği ödevleri takip etmesi, çocuğun düzenli olarak bireysel çalışma yapıp yapmadığını kont- 
rol etmesi ve öğretmenin geri dönütlerini mutlaka dikkate alması gerektiği düşünülmektedir. Öğretmenlerin yarısından fazlasının aileler tarafından bu desteğin ve motivasyonun sağlandığını söylemesi olumlu bir durum olarak değerlendirilebilirken, öğretmenlerin üçte birinin bazı ailelerin sağladığını, bazı ailelerin sağlamadığını söylemesi ise toplumun bu konuda bilinç kazanabilmesi için müzik öğretmenlerine önemli görevler düştüğünü düşündürmektedir.

Ö-5: “Çoğu veli çocuğunu başından savmak, uğraşmamak için kursa gönderiyor."

Ö-8: "Bazı veliler destek ve motivasyon sağlıyor bazıları ise sağlamıyor. Dışarıya karşı bir gösteriş olarak çocuklarını derse getiren aileler de var, gerçekten çocuğuna faydalı bir beceri kazandırmak için getiren de. Gösteriş olsun diye derse getiren aileler ne yazık ki bu konularda çok ilgili olmuyor."

Ö-17: “Aileler kesinlikle destek ve motivasyon sağhlyor. Öğrenci çalgı çalmak ve müzik yapmak istediği zaman aile tarafindan destekleniyor. Aileler kendi zamanlarında bu imkânlara sahip olmadı̆̆̆ için şimdi çocuklarının bir çalğ çalmasım ve müzik eğitimi almasın istiyor."

Tablo 21. Öğretmenlere göre ailede müzikle ilgilenen veya çalgı çalan başka bireyler olması durumunun öğrenci üzerindeki etkileri

\begin{tabular}{lll}
\hline Görüşler & f & \% \\
\hline Olumlu yönde etkilemektedir & 20 & 80 \\
Hem olumlu hem olumsuz yönde etkilemektedir & 5 & 20 \\
Toplam & 25 & 100 \\
\hline
\end{tabular}

Tablo 21'e göre öğretmenlerin oldukça büyük bir kısmı ailede müzikle ilgilenen veya çalgı çalan başka bireyler olması durumunun öğrenciyi olumlu yönde etkileyeceği görüşünü ifade etmiştir.

Ailede çalgı çalan diğer birey çalgı çalmanın gerekliliklerini yerine getiriyor, düzenli olarak bireysel çalgı çalışması yapıyor ve sonucunda gelişim kaydediyorsa öğrenci için rol model konumunda olacağından oldukça olumlu sonuçlara sebep olabilir. Öte yandan özellikle daha küçük yaş öğrencilerde rekabet duygusu doğru yönetilemezse, öğrenci kendini sürekli diğer aile üyesi ile kıyaslayarak yetersiz olduğu hissine kapılıp pes edebilir. 
Ö-2: “Olumlu etkiler. Anne, baba veya kardeşten etkilenerek müziğge başlayan öğrencilerim var. Birlikte müzik yapıyorlar. Eşiyle beraber piyano trompet düet çalan öğrencim de var, abisine kemanla eşlik eden öğrencim de."

Ö-18: "Ailede çalgı çalan bir başka birey varsa bu durum çocuk için güzel bir örnek teşkil eder ve çocuğun çalgısını sevmesi, çalğ çalışması olumlu anlamda etkilenir."

Ö-23: "Öğrenciyi kesinlikle etkileyen bir durumdur ancak kendisinden daha iyi çalan birkaç yaş büyük kardeş kıskançlık duygusunun doğmasına sebep olabileceğinden eğitimci için iyi yönetilmesi gereken bir süreç doğurur, krize açık bir durumdur."

\section{Tartışma ve Sonuç}

\section{Birinci Alt Probleme İlişkin Sonuç ve Tartışma}

Öğretmenlerin çoğunluğu, keman çalmak için gerekli fiziksel ve işitsel özelliklere sahip olma durumunun önemli olduğunu düşünmekle birlikte, çalgıya başlangıç öncesinde öğrencilerin fiziksel ya da işitsel özelliklerine dikkat ettiğini belirtmiştir. Hancıoğlu (2010)'na göre özengen müzik eğitimi veren kurumlarda öğrencilerin seçeceği çalg1 belirlenirken kendi isteklerinin yanı sıra öğrencilerin fiziki yapılarının uygunluğu da göz önünde bulundurulmalıdır. Kurtçu (2012)'ya göre de, öğrencilerin çalgı seçimi sırasında fiziksel olarak çalgıya uygun olup olmadıkları dikkatle incelenmelidir. Ancak çalg1 eğitimi süreci zorlu ve sürekli bir çalışma süreci olduğundan, öğrencinin çalgısını sevmesinin ve kendi isteği ile seçmesinin, bu süreci azim ve kararlılıkla aşması bağlamında büyük önem taşıdığını düşündüğünü de belirtmiştir. Gidergi Alptekin (2010)'in belirttiğine göre, çocuğun çalgıya olan ilgisi, müzikal yatkınlık ve işitme, el ve parmakların yapısı gibi temel unsurlar göz önüne alınarak çalgı seçimi yapılabilir. Bunlara ek olarak, fiziksel ve işitsel özellikleri keman çalmak için yeterli olmayan öğrenciler ile çalışmayan öğretmenlerin tamamı, öğrencileri fiziksel ve işitsel gelişimleri için başka bir çalgıya, özellikle piyanoya yönlendirdiklerini dile getirmişlerdir. Angı ve Hamzaoğlu Birer (2013) de, keman çalmak için işitsel becerileri yeterli olmayan öğrencilerin sabit perdeli başka çalgıları tercih etmesini önermiştir. Ayrıca, keman çal- 
mak için fiziksel ve işitsel özelliklere sahip olmanın önemli olduğunu düşünmesine rağmen fiziksel ve işitsel özellikleri yetersiz olan öğrenciler ile kurum patronu isteği, ebeveyn isteği ya da öğrenci ısrarı nedeniyle çalışmak zorunda kalan öğretmenlerin olması da oldukça dikkat çekici sonuçlardandır.

Öğretmenlere göre öğrencilerin büyük bir kısmı çalg1 tercihini kendi yapmaktadır. Tokatlı ve Mustul (2020) da araştırmasında özengen müzik eğitimi kurumlarında çalgı eğitimi alan öğrencilerin çoğunun çalgı tercihlerini kendi isteği doğrultusunda gerçekleştirdiğini tespit etmiştir. Bu durum, araştırmanın sonucu ile benzerlik göstermektedir.

Öğretmenlerin büyük bir kısmı keman eğitimine başlamadan önce başka bir çalgı çalan ya da daha önce müzikle farklı etkileşimler içinde bulunmuş olan öğrenciler ile çalıştığını belirtmiştir. Öğretmenler bu durumun öğrenci üzerindeki etkileri ile ilgili olarak öğrencinin notayı alg1lama hızının daha yüksek olması ve daha az entonasyon problemi yaşaması gibi görüşler dile getirmiştir. Akpınar ve Öztosun Çaydere (2011)'nin aktardığına göre, Cynthia Richards ve Jerry L. Jaccards"in (2010), “Applying Kodály's principles to string instrument pedagogy (Kodály yönteminin telli çalgı pedagojisindeki uygulaması)" konulu makalesinde, çalg1 eğitimi almadan önceki müzik eğitiminin ne denli önemli olduğu vurgulanmıştır. Çocuklara küçük yaşlarda şarkılar öğretilerek, kulakların, beynin yani düşüncenin eğitilmesinden sonra çalgı eğitiminin verilmesinin gerektiği, böylece çocukların müziğin teori kısmıla birlikte müziğin uygulama kısmını da yaparak yaşayarak öğrenebileceği ve bu şekilde gerçek müzisyen olabileceği vurgulanmıştır.

Öğretmenlerin neredeyse yarısı, öğrencilerin hobi amacı ile keman eğitimi aldığını belirtirken, öğretmenlerin bir kısmı öğrencilerin meslek edinme amacı ile keman eğitimi aldığını dile getirmiştir. Hancıoğlu'nun 2010 yılındaki çalışmasının sonucunda da özengen müzik eğitimi kurumunda çalgı eğitimi alan öğrencilerin genelinin, çalg1 eğitimlerini hobi amaçlı yaptığı görülmüştür.

Öğretmenlerin büyük bir kısmının öğrencilerin ders dışında çalgıları üzerinde yaptığı çalışmaları yeterli bulmadığı sonucuna ulaşılmıştır. Öğretmenlerin bir kısmı ise öğrencilerin örgün eğitim gördükleri okulları ve ev ödevleri çok vakit aldığı için keman çalışmalarına gereken zamanı ayı- 
ramadıklarını belirtmiştir. Oktay (2017) araştırmasının sonucunda, kursiyerlerin bireysel olarak çalgı çalışmaya günde yarım saatten az zaman ayırdıklarını, buna karşın öğrencilerin büyük çoğunluğunun çalgılarını çok sevdiklerini ifade ettiğini tespit etmiştir. Çalgılarını çok seven ve çalgı çalma becerilerini geliştirmek isteyen öğrencilerin bu işe ayırdıkları sürenin bu denli az olmasının, yapılan işin ciddiyetinin yeterince anlaşılmadığını düşündürdügünü belirtmiştir. Büyükköse ve Yıldırım Orhan (2016)'ın araştırma bulgularına göre özengen müzik eğitimi alan ortaokul öğrencilerinin bir kısmının ders dişında çalgı çalmaya hiç zaman ayırmadığı, bir kısmının ise haftada bir kere çalgı çalışmak için zaman ayırdığı sonuçlarına ulaşılmıştır. Tokatlı ve Mustul (2020) da araştırmaları sonucunda özengen müzik eğitimi kurumlarında çalgı eğitimi alan öğrencilerin bireysel çalgı çalışmalarının yeterli olmadığı sonucuna ulaşmıştır. Ang1 ve Hamzaoğlu Birer (2013), her çalgıda olduğu gibi keman eğitiminde de başarıya ulaşmak için kısa ve kolay bir yol bulunmadığını, çalgı öğrencisinin düzenli bir şekilde günlük çalışmalarını uygulaması gerektiğini dile getirmiştir.

Öğretmenlerin neredeyse tamamı öğrencilerin derslere düzenli olarak katıldıklarını ifade etmiş̧ir. Karan (2011) yüksek lisans tezinin sonucunda; özengen müzik eğitimi veren kurumlarda çalg1 eğitimi alan öğrencilerin, eğitime çoğunlukla kendi istekleri ile ve ailelerinin teşviki ile başladıkları, severek ve isteyerek devam ettikleri ve zorunlu olmadıkça devamsızlık yapmadıklarını tespit etmiştir. Tokatlı ve Mustul (2020)'un çalışmasında da özengen müzik eğitimi kurumlarında çalgı eğitimi alan öğrencilerin çok büyük bir bölümünün çalgı dersine düzenli katılım sağlamakta ve az devamsızlık yapmakta olduğu sonucuna ulaşılmıştır.

Öğrencilerin keman eğitimini bırakma sebepleri ile ilgili olarak öğretmenlerin bir kısmı liseye-üniversiteye giriş sınavı hazırlıkları nedeniyle, bir kısmı ise maddi sebepler nedeniyle öğrencilerin dersleri bıraktığını ifade etmiştir. Ayrıca bireysel çalgı çalışmaya vakit bulamama ve bir çalgı öğrenme disiplininin zor gelmesi nedeniyle ve örgün eğitim kurumlarının yoğunluğu nedeniyle çalgı eğitimini bırakan öğrencilerin olduğu da tespit edilmiştir. İmik ve Dönmez (2017)'e göre “Günümüzde, özengen müzik severlerin ilgisi bazı durumlarda kendilerini profesyonel müzisyenliğe kadar taşıyabilmektedir fakat çoğu zaman bu ilgi, ekonomik ve sosyo-kültürel nedenlerden dolayı kısa sürmektedir". 


\section{İkinci Alt Probleme İlişkin Sonuç ve Tartışma}

Öğretmenlerin büyük bir kısmı çalıştıkları kurumda düzenli olarak konser etkinlikleri yapıldığını ve bu etkinliklerin öğrencilerin motivasyonunu artırdığını dile getirmiştir. Tebbs (2006), konserlerin keman eğitiminde motivasyonu artırmada önemli bir yeri olduğunu, bir resital yaklaştığında öğrencilerinin çalışma tempolarının arttığını belirtmiştir. Aynı zamanda bu resitaller sayesinde ailelerin çocuktaki gelişimi apaçık gözlemleyebildiğini ve çocuğun da derste öğrenemeyeceği özgüven ve stres ile başa çıkma gibi bazı becerileri sahnede öğrendiğini dile getirmiştir. Tepeli (2018)'ye göre de düzenlenen dinleti ve konser faaliyetleri, müzik dershanelerinin eğitim kalitesinin doğrudan ölçülebildiği önemli ortamlardır. Canlı olarak sunulan konser ve dinleti gibi faaliyetler yakın ve uzak ortamlara ulaşarak toplumda müziğe ilgi duyan geniş kitleler arasında önemli paylaşım ve etkileşimlerin gerçekleşmesini sağlar. Bu yolla özengen müzik eğitimi veren kurumların toplum kaynaşmasında ve ortak değerlerin paylaşımında önemli bir işlevi yerine getirdiği söylenebilir.

Öğretmenlerin yarısının görev yaptığı kurum öğrencileri kent içerisindeki sanatsal faaliyetlere yönlendirirken, diğer yarısı ise yönlendirmemektedir. Tebbs (2006), sahnede canlı olarak ya da kayıttan diğer keman sanatçılarını dinlemenin motivasyonu olumlu yönde etkilediğini belirtmiş ve keman öğrencilerinin senfonilere, oda müziği orkestralarının performanslarına gitmelerini önermiştir.

Öğretmenlerin yarısının görev yaptığı kurumda keman eğitimini destekleyici dersler verildiği ancak bu derslere ilgi ve katılım düzeyinin oldukça düşük olduğu sonucuna ulaşılmıştır. Hancioğlu (2010)'na göre "Çalg1 eğitimi, müzik eğitiminin diğer boyutlarıyla, özellikle işitme eğitimiyle bağlantılı olarak ele alınabilir ve çalgı eğitiminin işitme eğitimiyle paralel olarak yürütülmesi birçok açıdan önem taşımaktadır". Tarkum (2006)'a göre de keman öğretimindeki entonasyon sorunlarının çözümünde kulak eğitimi de önemli bir rol oynar, bu nedenle kulak eğitiminin de öncelikle dikkate alınması gerekir. Kulak eğitiminden kopuk bir keman öğretiminin amacına ulaşmasının güçleşeceği de aynı çalışmada belirtilmiştir. Tarkum (2006)'un aktardığına göre (Ginzburg, 28,29) özellikle eğitimin ilk aşamasında entonasyon için, solfejin büyük önemi olduğunu, bir müzik cümlesinin entonasyonunun çoğu zaman bu cümlenin solfejinin 
yapılmasıyla düzeltilebileceğini belirtmiştir. Yapılan solfejler sayesinde ton duygusunun gelişiminin sağlanacağ 1 da ilave edilmiştir. Ang1 ve Hamzaoğlu Birer (2013) de, keman eğitimiyle kulak eğitimi arasında doğrusal bir ilişki olduğu gerçeğinden hareketle, öğrencilerin kulak eğitimi derslerine de gereken ilgi ve önemi vermesinin ehemmiyetine dikkat çekmiştir.

Öğretmenlerin büyük bir kısmının görev yaptığı kurumda öğrencilerin düzenli olarak birlikte çalgı çalabilecekleri bir toplu ders olmadığı sonucuna ulaşılmıştır. Özay ve Öztürk (2008)'e göre çalgı eğitimi alan öğrenciler, çalgı çalma becerisi kazanmanın yanı sıra toplu müzik yapma becerilerini de geliştirirse beğenileri ve sosyal yönleri de gelişeceği için birey olarak kendilerini daha iyi ifade edebileceklerdir. Kurtçu (2012) çalışmasının sonucunda keman öğrencilerinin birlikte müzik yapmayı öğrenmeleri ve sahne deneyimi kazanmaları açısından sıklıkla bireysel dinletiler, orkestra konserleri ve öğretmen konserleri düzenlenmesinin eğitim sürecine olumlu katkılar sağlayacağını düşündügüunü belirtmiştir.

Araştırmaya katılan öğretmenlerin tümünün çalıştıkları kurum MEB'e bağlı olmasına rağmen, oldukça az sayıdaki öğretmen ders öğretim programının MEB tarafından ya da MEB-kurum yönetimi ortak kararı ile belirlendiğini ifade etmiştir. Ders öğretim programının belirlenme şeklini bilmeyen ve herhangi bir ders öğretim programı olmadığını belirten öğretmenler de bulunmaktadır. Öğretmenlerin büyük bir kısmının ders öğretim programını kendilerinin belirlediği sonucuna ulaşılmıştır. Bu kurumlarda ortak bir ders programı olmasının öğrencilerin gelişimi ve başarısı açısından önemli olduğu düşünülmektedir. Kurumlarda MEB tarafından belirlenen bir ders öğretim programı olsa dahi, yöneticiler öğretmenleri bu öğretim programına uyma konusunda yönlendirmediği için her öğretmen kendi ders öğretim programını kendi belirlemekte ve bu durumun da benzer kurumlar arasında nitelik olarak ciddi farklar olmasına yol açtığı düşünülmektedir. Hancıoğlu (2010)'nun araştırmasından elde edilen bulgulara göre de özengen müzik eğitimi veren kurumlarda ortak bir eğitim anlayışı ve öğretim programı yoktur. Ortak bir öğretim programı ve eğitim anlayışı olsa bile denetimler sadece yönetim tarafından zaman zaman yapılmaktadır. Özengen müzik eğitimi kurumlarında ortak bir çalgı eğitimi programının olmaması dershaneler arasında, hatta aynı dershanedeki öğretmenler arasında bile farklılıklara sebep olmaktadır. Ayrıca 
bu kurumların, mesleki müzik eğitimine hazırlayıcı özelliği ile, müzik bölümlerine öğrenci yetiştirdiği ve çok büyük kitlelere hitap ettiği için belli bir denetlemeden geçmesi gerektiği düşünülmektedir. Ulucak (2003) çalışmasında, lisans seviyesindeki gitar öğrencilerinden daha önce özengen müzik eğitimi kurumlarında gitar eğitimi almış olanların, aldıkları eğitimin niteliği bakımından kendi içlerinde büyük farklılıklar gösterdiğini, bu farklılıkların öğrencilerin gitar tekniklerinde, çaldıkları eserlerde, eser üzerindeki yorumlarında ortaya çıktığını belirtmiştir. Bir ders öğretim programının olmayışının, öğretmenleri başka arayışlara yönlendirdiğini ve öğretmenlerin bu aşamada, kendi bilgi birikimi ve tecrübesi doğrultusunda öğrencilere yol göstermeye çalıştığını, bunun sonucunda ise öğrencilerdeki eksiklik ve farklılıkların daha da arttığını ilave etmiştir. Bozdemir (2009)'e göre "Eğitimin taşıdığı önem münasebetiyle planlı ve programlı bir süreç olması kaçınılmazdır. Bir sürecin başarılı olması o sürecin planlanması ile doğru orantılıdır. Eğitim sürecinin de başarılı olması eğitim programlarının ihtiyaca uygun olarak belirlenmesi ile mümkün olabilir".

Öğretmenlerin büyük bir kısmının kurumdaki çalışma şartları ile ilgili olumsuz görüşleri olduğu tespit edilmiştir. Öğretmenlerin bir kısmı bu olumsuzlukları arka arkaya çok fazla derse girilmesi gerekmesi, ders arası ve yemek arası olmaması, kurumda öğretmenler odası olmaması şeklinde ifade etmiştir. Bunlara ek olarak öğretmenler dersliklerin çok küçük olması, dersliklerin çok soğuk ya da sıcak olması, havalandırmanın yetersiz olması, ses yalıtımının kötü olması ve öğretmenler odasının olmaması gibi olumsuz fiziksel koşulları da dile getirmiştir. Tepeli (2018)'in aktardığına göre; bir eğitimin amacı ne olursa olsun etkililiği ve verimliliği büyük oranda eğitim ortamının niteliğine bağlıdır. Her programın başarılı olabilmesi için eğitimde kullanılacak araç ve gereç, bunların etkili bir şekilde kullanılacak zengin bir ortamın olması esastır (Çilenti, 1988, s.36).

\section{Üçüncü Alt Probleme İlişkin Sonuç ve Tartışma}

Öğretmenlerin yarısından fazlası ailelerin müzik eğitimi veya çalgı çalmanın gereklilikleri gibi konularda öğrenciye yeterli desteği ve motivasyonu sağladığını belirtirken, öğretmenlerin bir kısmı bazı ailelerin sağladığını, bazı ailelerin sağlamadığını ifade etmiştir. Altuntaş (2007)'ın aktardığına 
göre Noie (2005), müzik eğitiminde anne ve babaya aktif bir rol düştüğünü, müzik eğitiminin anne ve babanın katılımı ile olması gerektiği görüşünü savunmaktadır. Türkmen (2010), çocuklarına özengen müzik eğitimi aldıran ailelerin aktif olması, belli aralıklarla dersleri takip etmesi gerektiğini belirtmiş ve bu sayede Türk toplumunun daha büyük bir kesiminin müzik konusunda bilinçleneceği görüşünü savunmuştur.

Öğretmenlerin büyük bir kısmının ailede müzikle ilgilenen veya çalg1 çalan başka bireyler olması durumunun öğrenci üzerinde olumlu etkileri olacağını düşündüğü sonucuna ulaşılmıştır. Maria Calissendorff'un (2006), "Understanding the learning style of pre-school children learning the violin "(Okul öncesi çocuklarının keman eğitimi sürecindeki öğrenme stilini anlamak) isimli makalesinde, özellikle küçük yaştaki çocukların çalgı eğitiminde velilerin çok önemli bir rolü olduğu, kendisi de müzisyen olan ya da bir çalg1 çalabilen velinin, çocuk için güzel bir örmek olabileceği, öğretmen ve veli işbirliğinin çocuğun çalgı eğitiminde çok önemli bir yere sahip olduğu belirtilmiştir.

\section{Öneriler}

1- Özengen müzik eğitimi kurumlarının büyük bir kısmında keman eğitimi destekleyici derslerin verilmediği, öğrencilerin birlikte düzenli olarak çalgı çalabileceği bir toplu ders olmadığı ve kurumun öğrencileri kent içerisindeki sanatsal faaliyetlere yönlendirmediği sonuçlarına dayanarak, özengen müzik eğitimi kurumlarında bireysel yapılan keman dersine ek olarak işitme, solfej ve orkestra derslerinin verilmesi ve bu kurumların kent içerisindeki sanatsal faaliyetleri takip ederek öğrencilerini yönlendirmesi önerilmektedir.

2- Özengen müzik eğitimi kurumlarında görev yapan öğretmenlerin bir kısmının keman çalmak için gerekli fiziksel ve işitsel özelliklere sahip olma durumunun önemli olduğunu düşünmesine rağmen, kendi isteği dışında (kurum patronu isteği, ebeveyn isteği ve öğrenci 1srarı) fiziksel ve işitsel özellikleri keman çalmak için yeterli olmayan öğrenciler ile çalıştığı sonucuna dayanarak, özengen müzik eğitimi kurumlarının ticari kaygılardan arındırılması, çalgı 
eğitimi başlangıcı öncesinde öğrencinin fiziksel ve işitsel özelliklerinin dikkate alınması ve bu özelliklere uygun çalgılara yönlendirilmesi önerilmektedir.

3- Özengen müzik eğitimi kurumlarında görev yapan öğretmenlerin büyük bir kısmının çalışma koşullarından memnun olmadığı sonucuna dayanarak; öğretmenlerin dinlenme, beslenme gibi temel ihtiyaçlarının göz önünde bulundurulması, bu kurumlardaki ders programlarının yoğunluğunun azaltılması, bir gün içerisinde art arda 8 saatten fazla ders yapılmaması, ders sürelerinin maksimum 40 veya $45 \mathrm{dk}$. olması ve öğretmenlerin verimliliğinin düşmemesi adına dersler arasında mutlaka boşlukların olması, kurum içerisinde bu boşluklarda öğretmenlerin dinlenebileceği, yemek yiyebileceği kendilerine özel bir alanın tahsis edilmesi önerilmektedir.

4- Özengen müzik eğitimi kurumlarında görev yapan öğretmenlerin kurumların fiziksel şartları ile ilgili olumsuz görüşleri olduğu sonucuna dayanarak bu kurumlarda dersliklerin ses yalıtımına, dersliklerin havalandırılabilir olmasına, dersliklerin çok küçük olmamasına dikkat edilmesi önerilmektedir.

5- Özengen müzik eğitimi sürecinde öğretmen görüşlerine göre ailelerin bir kısmının öğrencilere çalgı eğitimi sürecinde yeterli desteği ve motivasyonu sağlamadığı sonucuna dayanarak, ebeveynlerin bu süreçte çocuklarını yakından takip ederek desteklemesi önerilmektedir.

6- Özengen müzik eğitimi kurumlarında görev yapan öğretmenlerin öğrencilerin bireysel çalgı çalışmalarını yetersiz bulduğu sonucuna dayanarak, özengen müzik eğitimi sürecinde bir çalg1 üzerinde gelişim göstermek isteyen her öğrencinin düzenli olarak sabırla çalgı çalışması önerilmektedir. 
EXTENDED ABSTRACT

\title{
The Problems Faced by the Teachers Who Conduct Violin Lessons in the Institutions Teaching Amateur Music
}

\author{
Beyza Tokatl1- Önder Mustul \\ Necmettin Erbakan Univesity
}

Amateur music education is an important sub-dimension of music education with its supporting role in general music education and with its preparatory role for vocational music education. It is noteworthy that studies in the field of amateur music education have focused in recent years on institutions that provide music education towards this goal. It is seen that the field of instrument education comes to the fore in the institutions of amateur music education, compared with other fields of music education. It is thought that the research carried out in order to determine the problems in the institutions of amateur music education and to offer solutions will help to increase the quality of the education given in these institutions. In this study, the aim is to determine the problems faced by the teachers who conduct violin lessons in amateur music education institutions affiliated to the Ministry of National Education, due to students, parents and institutions, and to offer solutions according to the findings.

This research is of great importance as it aims to identify the problems faced by teachers who conduct violin lessons in amateur music education institutions and to offer solutions regarding the subject; also, among the very limited number of studies on amateur music education, it is the first research on teachers who conduct violin lessons in amateur music education institutions. In addition, it is considered that it will contribute to the way of conducting violin lessons in a more qualified way in amateur music education institutions. Besides, this research is also important in terms of being a source for teachers, parents, students who are interested in amateur music education and for future research on related issues. 


\section{Method}

Working group: The participants of this research consist of 25 available violin teachers who wanted to contribute to the research voluntarily and who were actively conducting violin lessons in amateur music education institutions affiliated to the Ministry of National Education in the provinces of Istanbul, Konya, İzmir, Ankara, Amasya, Antalya, Balıkesir, Batman, Çanakkale, Denizli and Kocaeli.

Data Collection and Analysis: The research is a descriptive study in the general survey model, which is one of the scientific research models. In order to provide a theoretical basis for the research, the resources related to music education, amateur music education, instrument education and violin education were scanned and examined. The interview questions prepared in line with the data obtained as a result of the scanning and with the general purpose of the research in order to determine the problems faced by the teachers who conducted violin lessons in amateur music education institutions were developed with expert opinions and with a pilot application, and the findings were obtained by applying them on the predetermined study group. A structured interview form consisting of a total of 30 open-ended questions prepared by the researcher with expert opinion was used in the research. While the interview form was being prepared, 39 questions were prepared in a question pool. Then, the number of the questions was reduced to 30 . While applying the interview form, necessary explanations were made to the working group, and it was emphasized that their answers would be kept confidential and the importance of giving sincere and honest answers was emphasized. Descriptive analysis was carried out on the data obtained as a result of the interviews, in accordance with the data collection technique. The data were tabulated using frequency and percentage calculations from descriptive statistical methods. 
Results: The findings obtained as a result of the analysis of the data collected through the research questions are included in this section. According to this;

- Three-quarters of the teachers stated that they paid attention to the physical or auditory characteristics of the students before starting the instrument.

- Most of the teachers thought that it was important to have the necessary physical and auditory characteristics to play the violin. In addition, the majority of teachers stated that they worked with students whose physical and auditory characteristics were not sufficient to play the violin. According to the data, there were 5 teachers who had to work with students whose physical and auditory characteristics were not sufficient to play the violin, although they thought that it was important to have the necessary physical and auditory characteristics to play the violin.

- The majority of teachers working with students whose physical and auditory characteristics were not sufficient to play the violin stated that it was more important for the student to be interested and willing. It is quite remarkable that one third of the teachers worked with students whose physical and auditory characteristics were not sufficient to play the violin, against their own will (due to a desire of the boss of the institution, upon the request of the parent or request of the student).

- It is seen that most of the teachers thought that students with insufficient auditory abilities couldn't progress due to the fact that the violin is a fretless instrument, and therefore it is important to have the necessary physical and auditory characteristics to play the violin.

- The majority of the teachers stated that the students chose an instrument because of being influenced and emulated by the individuals around them or because of the popularity of the instrument.

- Most of the teachers worked with students who played another instrument or had different interactions with music before starting violin education.

- Most of the teachers stated that the students continued their instrument education as a hobby.

- Most of the teachers stated that the studies on the instruments of the students outside the classroom were not sufficient. 
- Almost all of the teachers stated that the students attended the classes regularly.

- Most of the teachers have encountered students who dropped out of violin education. Most of the teachers stated that the students quit their education due to the preparation for the high school-university entrance exam or due to financial reasons.

- Most of the teachers stated that the students were interested in and enthusiastic about playing instruments, albeit partially.

- Concert events were held regularly in the institution where most of the teachers worked.

- The majority of the teachers remarked that their institutions didn't direct students to artistic activities in the city, that there were no lessons to support violin education in their institutions, and that there were no collective lessons in which instruments were played together on a regular basis.

- Although all of the teachers included in the research group are affiliated with the Ministry of National Education, it is remarkable that only one-fourth of them stated that the curriculum was determined by the Ministry of National Education or by the joint decision of the Ministry of National Education and the Institution management.

- While approximately one-third of the teachers rated the working conditions in the institution as very positive, two-thirds of them made negative evaluations, which is thought-provoking in terms of the functioning of these institutions.

- It is seen that most of the teachers stated that they were satisfied with the curriculum.

- The majority of teachers expressed that families provided sufficient support and motivation to students in subjects such as musical education or the requirements of playing an instrument.

- Most of the teachers were of the opinion that if there were other members of the family who were interested in music or who played an instrument, it would affect the students positively. 
Conclusion: It is concluded that the teachers who conduct violin lessons in amateur music education institutions have various problems with three groups in total: "student performances", "the functioning of the institution" and "opinions about student families", as well as with the subjects within these groups.

\section{Kaynakça/References}

Akpınar, G. ve Öztosun Çaydere, Ö. (2011). Başlangıç keman eğitiminde kullanılabilir okul şarkıları, türküler ve tekerlemeler. ISSN:1306-3111 e-Journal of New World Sciences Academy, 6(2), 290-302.

Aksoy, Y. (2015). Özengen keman eğitiminde video destekli öğretimin keman performansina etkisi. Necmettin Erbakan Üniversitesi, Eğitim Bilimleri Enstitüsü, Güzel Sanatlar Eğitimi Anabilim Dalı, Müzik Öğretmenliği Bilim Dalı, Konya.

Altuntaş Saçlığlu, E. (2007). 7-11 yaş grubu çocuklarmda keman eğitimi. Yüksek Lisans Tezi. Abant İzzet Baysal Üniversitesi, Sosyal Bilimler Enstitüsü, Güzel Sanatlar Eğitimi, Anabilim Dalı, Müzik Eğitimi Bilim Dalı, Bolu.

Ang1, Ç.E. ve Hamzaoğlu Birer, A.R. (2013). Keman öğretiminde karşılaşılan entonasyon problemleri ve çözüm önerileri. Sanat Eğitimi Dergisi, 1(2), 4869.

Bozdemir, Z. (2009). Yayg̨n eğitim sürecinde yerel yönetimlerin rolü. Yüksek Lisans Tezi. Kırıkkale Üniversitesi, Sosyal Bilimler Enstitüsü, Eğitim Bilimleri Anabilim Dalı, Kırıkkale.

Büyükköse, A., Yıldırım Orhan, Ş. ve Şeren, M. (2016). Amatör müzik eğitiminin, ortaokul öğrencilerinin problem çözme becerilerine etkisi (Kırıkkale ili örneği). International Periodical for the Languages, Literature and History of Turkish or Turkic Volume 11/21, 565-582.

Calissendorff, M. (2006). Understanding the learning style of pre-school children learning the violin. Music Education Research, 8(1), 3-96.

Gidergi Alptekin, A. (2010). 06-15 yaş arası çocuklarda keman eğitimi, uygulanan metotlar ve bu eğitimin çocukların fiziksel ve psikolojik gelişimlerine etkileri. Mimar Sinan Güzel Sanatlar Üniversitesi Sosyal Bilimler Enstitüsü Müzik Ana Sanat Dalı Yaylı Çalgılar Programı Sanatta Yeterlik Tezi. İstanbul. 
Hancıoğlu, G. (2010). Ankara'daki özengen (amatör) müzik eğitimi veren kurumlarm eğitim anlayışları ve yönetim biçimleri üzerine genel bir inceleme. Yüksek Lisans Tezi. Gazi Üniversitesi, Eğitim Bilimleri Enstitüsü, Güzel Sanatlar Eğitimi Bölümü, Müzik Öğretmenliği Ana Bilim Dalı, Ankara.

İmik, Ü. ve Dönmez, Y. E. (2017) Özengen müzik eğitimi veren kurumlarda Türk müziği ilgisi: Malatya örneği. İnönü Üniversitesi Kültür ve Sanat Dergisi, 3(2), 114-128.

Karan, M. (2011). Özengen müzik eğitimi veren kurumlarda çalgı eğitimi alan öğrencilerin mesleki yönelimlerinin incelenmesi. Yüksek Lisans Tezi. Gazi Üniversitesi, Eğitim Bilimleri Enstitüsü, Güzel Sanatlar Eğitimi Anabilim Dall, Müzik Öğretmenliği Bilim Dalı, Ankara.

Kurtçu, E. (2012). Güzel sanatlar fakülteleri müzik bölümü müfredatlarmda bulunan keman eğitimi derslerinde yaşanan sorunlarm öğrenci ve öğretmen görüşleri doğrultusunda incelenmesi. Yüksek Lisans Tezi. Atatürk Üniversitesi, Sosyal Bilimler Enstitüsü, Müzik Bilimleri Ana Sanat Dalı, Erzurum.

Oktay, C. (2017). Türkiye'de özengen müzik eğitiminde uluslararası sertifikalı müzik eğitimi programlarmın işlevinin incelenmesi. Yüksek Lisans Tezi. Marmara Üniversitesi, Eğitim Bilimleri Enstitüsü, Güzel Sanatlar Eğitimi Anabilim, Dalı Müzik Öğretmenliği Bilim Dalı, İstanbul.

Özay, S. ve Öztürk, F. G. (2008). Keman ve viyola eğitiminde kullanılan Mazas "Special Etudes Op.36" Metodu'nun sağ ve sol el teknikleri yönünden incelenmesi. GÜ, Gazi Ĕ̆itim Fakültesi Dergisi, 28(3), 57-74.

Özdemir, S. (2015). Amatör keman eğitiminde amaç ve hedeflere göre keman öğretim metotlarmın ve tekniklerinin incelenmesi. Yüksek Lisans Tezi. Gazi Üniversitesi, Eğitim Bilimleri Enstitüsü, Güzel Sanatlar Eğitimi Anabilim Dalı, Ankara.

Tarkum, E. (2006). Entonasyon açısından keman öğretimi. Trakya Üniversitesi Sosyal Bilimler Dergisi, 8(2), 121-126.

Tebbs, J. (2004). Motivating your student/child to practice. The violin Case, LLc, Kirkland, WA. https://shop.theviolincase.com/pages/February-2004.html

Tepeli, H. (2018). Ankara'daki özengen müzik eğitimi veren kurumlarmn çok yönlü incelenmesi. Yüksek Lisans Tezi. Necmettin Erbakan Üniversitesi Eğitim Bilimleri Enstitüsü ,Güzel Sanatlar Eğitimi Anabilim Dalı, Müzik Eğitimi Bilim Dalı, Konya.

Tokatlı, B. ve Mustul, Ö. (2020). Özengen müzik eğitimi sürecinde çalg1 eğitimi alan öğrencilerin çalgı çalışmalarını etkileyen faktörler. Gece Kitaplı̆̆ı. Güzel Sanatlar Alanında Akademik Çalşmalar - II, Bölüm 4. 59-82. 
Türkmen, U. (2010). Çocuğun bireysel, toplumsal ve kültürel gelişiminde amatör müzik eğitiminin yeri, problemleri ve çözüm önerileri. İlköğretimonline, 9(3), 960-970.

Uçan, A. (1997). Müzik eğitimi temel kavramlar-ilkeler-yaklaşımlar ve Türkiye'de Cumhuriyetin ilk altmış yılındaki durum. Ankara: Müzik Ansiklopedisi Yayınları.

Uslu, M. (2012). Nitelikli keman eğitimine yönelik yaklaşımlar. Eğitim ve Öğretim Araştırmaları Dergisi, 1(4), 1-11.

Yıldırım, A., Şimşek, H. (2018). Sosyal bilimlerde nitel araştırma yöntemleri. Ankara: Seçkin Yayıncllık.

\section{Kaynakça Bilgisi/Citation Information}

Tokatlı, B. ve Mustul, Ö. (2021). Özengen müzik eğitimi kurumlarında keman derslerini yürüten öğretmenlerin karşılaştığı problemler. OPUS-Uluslararası Toplum Araştırmaları Dergisi, 18(43), 6595-6634. DOI:10.26466//opus.910883. 